\title{
Hubungan Antar Umat Beragama (Studi Kritis Metodologi Penafsiran Tekstual)
}

\author{
Ahmad Taufik ${ }^{1}$
}

\begin{abstract}
The textual interpretation of the Qur'an has been considered as the most valid and authoritative method in interpreting the Qur'an. However, this method has many weaknesses because it can produce intolerant and exclusive religious attitude. Therefore, an interpreter needs to consider not only the analysis of the text of the Qur'an but also its context of revelation.

This statement is proven by analyzing the interpretation of Nassir al-Sa'di on inter religious relation. The data is first analyzed using the thematic approach. This approach is used to collect verses related to interreligious relation. In the next step, this interpretation is analyzed by contextual approach as proposed by Abdullah Saeed.
\end{abstract}

\begin{abstract}
Abstrak
Metodologi penafsiran tekstual sudah terlanjur dianggap sebagai metode yang paling sah dan otoritatif dalam menafsirkan ayat alQur'ān. Padahal, metode tersebut memiliki sejumlah kelemahan karena dapat memicu tumbuhnya sikap beragama yang intoleran dan eksklusif. Karena itu, seorang penafsir hendaknya tidak hanya terpaku kepada analisis teks semata tapi juga memperhatikan konteks teks saat diturunkan.

Pernyataan tersebut dibuktikan dengan menganalisis penafsiran Nașr al-Sa'di yang terkait dengan hubungan antar umat beragama. Data tersebut pertama kali dianalisis dengan menggunakan metodologi tafsīi al-mauḍu'ì. Pendekatan ini dipakai untuk mengumpulkan ayat yang terkait dengan hubungan antar umat
\end{abstract}

1 Peneliti di Pusat Studi Qur'an (PSQ), Lentera Hati, Jakarta. E-mail: taufiqa22@yahoo.com 
beragama. Pada tahap selanjutnya, penafsiran tersebut dianalisis berdasarkan pendekatan kontekstual yang dirumuskan oleh Abdullah Saeed.

Keywords: Tekstual, Kontekstual, tafsīr al-maudūùt, intoleran dan eksklusif.

\section{Pendahuluan}

Penafsiran ayat yang terkait hubungan antar umat beragama hingga saat ini masih menjadi perdebatan di kalangan para mufasir. Metode penafsiran klasik dianggap bisa melahirkan penafsiran yang bersifat eksklusif karena nonMuslim dipandang sebagai musuh (enemy) yang selalu berupaya memperdaya umat Islam. ${ }^{2}$ Ini disebabkan metode penafsiran yang digunakan adalah metode kebahasaan yang cenderung tekstual. Dalam perspektif tekstualis, pendekatan bahasa diyakini dapat mengakomodir maksud pengarang secara utuh. Itulah sebabnya, fokus utamanya adalah identifikasi maksud pengarang teks dengan menggunakan pendekatan kebahasaan (philologically centred approach). Metode ini dinilai sebagai media yang paling sah, otoritatif, dan dapat menghasilkan pemahaman yang objektif terhadap penafsiran teks al-Qur'ān. ${ }^{3}$

Pemikiran tersebut dikritik oleh kelompok Muslim Progressif (Kontekstualis) karena penafsiran yang dihasilkan dari tradisi penafsiran klasik berasal dari metodologi tafsir yang bersifat atomis dan parsial. Abdullah Saeed menyebutkan bahwa panafsiran legal-ethic al-Qur'ān tidak dapat lagi memenuhi kebutuhan umat Islam dewasa ini. Karena itu, jika wacana re-interpretasi alQur'ān tidak segera dilaksanakan, maka legal-ethic al-Qur'ān lambat laun akan segera diabaikan, dan umat Islam akhirnya mengabaikan pesan al-Qur'ān. ${ }^{4}$ Abū Zayd (w. 2003 M) menyebutkan bahwa re-interpretasi teks al-Qur'ān sesuai latar historis dan sosial masyarakatnya adalah suatu hal yang lumrah. Ini bertujuan untuk menggantikan interpretasi lama dengan interpretasi yang lebih

2 Ahmad Taufik, "Tekstualitas Penafsiran al-Qur'an: Kritik Metodologi Tafsir" (Jakarta: Cinta Buku Media, 2014), 203-206.

3 Adis Duderija, "Neo-Traditional Salafi Qur'an-Sunna Hermeneutics and Its Interpretational Implications," 319. Lihat juga, Adis Duderija, "Neo-Traditional Salafi Qur'an-Sunnah Hermeneutic and the Construction of a Normative Muslimah Image," HAWWA 5, 2-3 (2007): 289-323: 300.

${ }^{4}$ Abdullah Saeed, Interpretating the Qur'an: Towards a Contemporary Approach (London dan New York: Routledge, 2006), 3. 
mutakhir, yakni yang lebih humanistik dan maju, tanpa mengubah kata-kata harfiah teks al-Qur'ān sedikitpun. ${ }^{5}$

Kalangan kontekstual meyakini bahwa persoalan sosial dapat diselesaikan melalui proses dialektik antara teks al-Qur'ān dan perkembangan masyarakat. ${ }^{6}$ Pembacaan secara literal (philological approach) dinilai tidak dapat mengakomodir kebutuhan masyarakat. Meskipun teks al-Qur'ān telah final dan menjadi corpus resmi umat Islam, tapi ia harus selalu relevan dengan perkembangan masyarakat. Karena itu, perlu kajian spesifik mengenai kondisi sosial masyarakat dan konteks sosio-historis penurunan wahyu. Pengabaian situasi sosial dapat mengakibatkan produk hukum yang kontra produktif dan tidak sesuai dengan kebutuhan masyarakat. ${ }^{7}$ Karena itu, seorang penafsir jangan hanya terlena dengan analisis teks semata, tapi juga harus melakukan contextual and historical reading. Proses tersebut mencakup konteks historis, sosial, dan politik saat teks diturunkan yang bertujuan untuk membebaskan umat Islam dari pemahaman secara tekstual (literal reading). ${ }^{8}$

Meski demikian, menurut kalangan tekstual umat Islam seharusnya merujuk pada ketentuan al-Qur'ān, karena ia diturunkan untuk menjawab dan mengatasi berbagai persoalan yang menimpa umatnya. Islam adalah agama yang paling rasional dibandingkan agama lainnya, sehingga antara nilai ideal alQur'ān dan perkembangan sosial dapat disatukan dengan merujuk pada ketentuan al-Qur'ān. ${ }^{9}$ Walaupun, al-Qur'ān turun pada abad ke-VII hijriah, dengan objek masyarakat Arab pada masa itu, tapi ia bersifat universal dan akan selalu relevan dengan berbagai situasi dan kondisi. Transformasi budaya hanya dapat dilakukan dengan merujuk pada teks al-Qur'ān. Kelompok Salafi

\footnotetext{
${ }^{5}$ Moch Nur Ichwan, Meretas Keserjanaan Kritis al-Qur'an: Teori Hermeneutika Nașr Abü Zayd (Jakarta Selatan: Teraju, 2003), 4.

${ }^{6}$ Kecenderungan ini dapat dilihat dalam berbagai karya kelompok Muslim Progresif yang berupaya menghubungkan antara konteks pewahyuan dengan konteks masyarakat kontemporer saat ini, dengan memperhatikan kondisi sosial dan nilai yang berkembang, seperti pluralisme agama (religious pluralism), kesetaraan gender (gender equality), dan keadilan (justice). Lihat: Clinton Bennett, Interpreting the Qur'an: A Guide for the Uninitiated. Ingrid Mattson, The Story of the Qur'an: Its History and Place in Muslim Life (Oxford: Blackwell Publishing, 2008). Omid Safi (ed), Progressive Muslims.

${ }^{7}$ Abdullah Ahmed An-Na'im, Toward an Islamic Reformation: Civil Liberties, Human Rights, and International Law (New York: Syracuse University Press, 1990), 182-187.

${ }^{8}$ Rachael M. Scott, “A Contextual Approach to Women's Rights in the Qur'ān: Readings of 4:34" The Muslim World 99,1 (2009): 60-85: 61.

9 Massimo Campanini, The Qur'an: Modern Muslim Interpretations, terj. Caroline Higgitt (London dan New York: Routledge, 2011), 8-10.
} 
misalnya terkenal dengan slogan kembali pada al-Qur'ān dan Sunnah. Ayat alQur'ān diyakini pula bersifat statis, normatif, sehingga hukumnya bersifat final, dan tidak mengalami perubahan. Pernyataan tersebut didukung oleh sejumlah ayat, yang menyatakan bahwa al-Qur'ān telah sempurna. ${ }^{10}$

Metode penafsiran tekstual hingga saat ini masih banyak diterapkan dan telah menjadi metode yang paling banyak digunakan dalam kancah penafsiran al-Qur'ān kontemporer. Kelompok tekstual berargumen bahwa metode panafsiran tekstual adalah cara yang paling sah dan otoritatif dalam penafsiran (interpretation) karena langsung merujuk pada sumber asli yaitu al-Qur'ān, hadis, dan para Sahabat (Khulafä' Rāshidin). ${ }^{11}$ Metode tersebut juga digunakan oleh tokoh mufasir kontemporer seperti ‘Abd Allāh bin Bāz (w. 1999 H), Nāṣir al-Sa'di (w. 1956 H), dan Muhammad 'Uthaymin (w. 2001 H) ketika menafsirkan nash al-Qur'ān terutama yang berkaitan dengan hubungan antar umat beragama (religious community).

Tulisan ini berfokus pada metode penafsiran tekstual yang digunakan oleh al-Sa'di dalam menafsirkan ayat yang terkait dengan hubungan antar umat beragama. Ayat yang akan menjadi fokus kajian adalah QS. al-Baqarah [2]: 120 dan QS. al-Mai'dāh [5]: 51. Pengambilan dua ayat ini bertujuan untuk menelusuri pandangan mufasir tekstualis terhadap umat agama lain (nonMuslim). Ayat lainnya juga akan dirujuk supaya pandangan seorang mufasir atas komunitas lainnya (non-Muslim) dapat dibaca secara komprehensif dan tidak parsial. Pembahasan dua ayat di atas cukup beralasan karena penafsiran terhadap dua ayat ini masih menjadi perdebatan di antara para mufasir baik antara kelompok tekstualis-kontekstualis, eksklusif-inklusif, dan fundamentalisprogresif.

Dalam penelitian ini akan digunakan sejumlah pendekatan, antara lain adalah pendekatan tafsir mauḍu $\bar{i}$. Ini bertujuan untuk mengumpulkan ayat yang

${ }^{10}$ Berdasarkan penelusuran terhadap tiga tafsir Salafi, yaitu Taysir al-Karim alRahmān karya Muhammad Nāṣir al-Sa'di (1889-1956), Adwä, al-Bayān karya Muhammad Amīn al-Shinqițī (1907-1973), dan Aysār al-Tafsî̀ oleh Abū Bakar Jabïr alJazirīi (1921), ditemukan bahwa kecenderungan tafsir Salafi adalah bersifat literal (wooden literalism), dan menutup berbagai kemungkinan makna. Ini disebabkan oleh generalitas pembacaan ayat, dan al-Qur'an dianggap sebagai language, bukan sebagai discourse. Lihat: Izza Rohman, "Salafi Tafsirs: Textualist or Authoritarian," Qur'an and Hadith Academic Society 1, 2 (2012): 197-213: 201-206. Isyarat terkait kesempurnaan ajaran Islam terdapat dalam Q.S al-Mā'idah [5]: 3. Q.S al-An'ām [6]: 115.

11 Adis Duderija, "The Interpretational Implications of Progressive Muslims' Qur'an and Sunna Manhāj in Relation to their Formulation of a Normative Muslima Construct," Islam and Christian-Muslim Relations 19,4 (2008): 411-429: 416. 
terkait dengan hubungan antar umat beragama. Langkah selanjutnya memakai pendekatan hermeneutika kontekstual yang dirumuskan oleh Abdullah Saeed. Kekuatan utama metode ini terletak pada analisis sosio-historis ketika teks diturunkan dan saat teks hendak ditafsirkan. Langkah yang dirumuskan oleh metode hermeneutika kontekstual akan digunakan untuk menganalisis pendekatan maupun produk tafsir tekstual al-Sa'di.

Berdasarkan paparan di atas, terlebih dahulu penulis akan mengemukakan defenisi dan langkah penafsiran tekstual maupun kontekstual. Hal ini dianggap perlu karena kategori tersebut akan digunakan untuk menganalisis penafsiran tekstual al-Sa'di dan juga sekaligus mengkritisi metodologinya melalui cara pandang kontekstual. Setelah diperjelas dua kecenderungan tersebut, maka dipaparkan penafsiran al-Sa'di mengenai hubungan antar umat beragama. Pada tahap akhir, penafsiran tersebut akan dianalisis dengan menggunakan perspektif sejarah, dan hermeneutika kontekstual.

Terdapat tiga perbedaan utama antara metodologi penafsiran tekstual dan kontekstual, yaitu: [1]. Letak otentisitas makna [2]. Penerapan analisis konteks teks, dan [3]. Proses penarikan legal-ethics al-Qur'ān.

\section{Paradigma Tekstual dan Kontekstual: Teks, Konteks dan Interpretasi}

Penarikan makna, pada dasarnya, terkait erat dengan teori penafsiran, atau yang dikenal dengan istilah hermeneutika, yaitu bagaimana sebuah makna diperoleh dan bagaimana peran pembaca, pengarang, dan teks itu sendiri. ${ }^{12}$ Dalam kaitan ini, kalangan tekstualis tidak mengakui unsur hermeneutika di atas, karena mereka mendasarkan epistemologi penafsiran pada manhaj ahlhadith. Fokus utamanya adalah identifikasi maksud pengarang teks, dengan menggunakan pendekatan kebahasaan (philologically centred approach). Pendekatan bahasa diyakini dapat mengakomodir maksud pengarang secara

12 Mengutip Rudolf Bultman, Farid Essack menegaskan bahwa hermeneutika adalah istilah secara umum yang "dipakai untuk mendiskripsikan upaya menjembatani jurang antara masa lalu dan masa kini”. Farid Essack, Qur'an, Liberation, and Pluralism: an Islamic Perspective of Interreligious Solidarity against Oppression (Oxford: Oneworld Publication, 1997), 83. Proses penarikan makna, pada dasarnya, dipengaruhi oleh sejumlah faktor, yaitu: a) pembaca (perangkat keilmuan, gender, pengalaman, karakter, perkembangan pembaca, dan kondisi sosio-kultural di mana ia tinggal); b) tujuan pengarang; c) teks (konteks dan mekanisme bahasa). Lihat, Adis Duderija, "NeoTraditional Salafi Qur'an-Sunna Hermeneutics and Its Interpretational Implications," Religion Compass 5,7 (2011): 314-325: 319. 
utuh dan dinilai sebagai media yang paling sah, otoritatif, dan dapat menghasilkan pemahaman yang objektif terhadap penafsiran teks al-Qur'ān. ${ }^{13}$

Sementara itu, tokoh kontekstual menegaskan bahwa pembaca (penafsir) mempunyai peran yang sangat signifikan dalam proses penarikan makna. Teks al-Qur'ān dapat saja didekati dengan beragam metode, sehingga menghasilkan aneka penafsiran. Jika teks dipahami oleh penafsir yang berbeda, dapat saja menghasilkan interpretasi yang berbeda pula, karena dipengaruhi oleh faktor sosio-historis, dan pengalaman seorang penafsir. ${ }^{14}$ Farid Esack menegaskan bahwa para penafsir pasti terpengaruh oleh keadaan dan lingkungan tempat ia berada. Itulah sebabnya, para mufasir semenjak masa Nabi Muhammad saw memahami teks al-Qur'ān dengan aneka ragam penafsiran, karena setiap penafsir ketika memasuki proses interpretasi pasti membawa pemahaman awal (pre-suppossion) dan menyertakan konsepsinya sendiri sebagai asumsi awal penafsiran. $^{15}$

Berdasarkan paradigma tersebut, pemahaman teks tidak dapat ditentukan oleh kelompok mana pun, baik oleh pengarang (author) ataupun pembaca (reader) secara sepihak. Pemahaman teks dapat saja menghasilkan produk tafsir yang beragam, karena adanya interaksi yang hidup antara pengarang (author), teks (text), dan pembaca (reader). Jika seorang penafsir menghilangkan peran pengarang (author) ataupun teks (text), sehingga kebenaran hanya berdasarkan pandangan pembaca (reader). Penafsiran model ini dapat melahirkan interpretative despotism (kesewenang-wenangan penafsiran). ${ }^{16}$ Meski demikian,

13 Adis Duderija, "Neo-Traditional Salafi Qur'an-Sunna Hermeneutics and Its Interpretational Implications," 319. Lihat juga, Adis Duderija, "Neo-Traditional Salafi Qur'an-Sunnah Hermeneutic and the Construction of a Normative Muslimah Image," HAWWA 5, 2-3 (2007): 289-323: 300.

14 Adis Duderija, "The Interpretational Implications of Progressive Muslims' Qur'an and Sunna Manhaj in Relation to their Formulation of a Normative Muslima Construct,"Islam and Christian-Muslim Relations 19,4 (2008): 411-429: 416.

${ }^{15}$ Farid Esack, Qur'an, Liberation, and Pluralism: An Islamic Perspective of Interreligious Solidarity against Oppression (Oxford: Oneworld, 1998), 82-110. Nașr Hāmid Abū Zayd juga menekankan adanya peran mufasir dalam produksi makna, karena menurutnya, makna dihasilkan dari proses dialektika antara pengarang dan pembaca (jadaliyya). Lihat, Yusuf Rahman, "The Hermeneutical Theory of Nașr Hāmid Abū Zayd: An Analytical Study of His Method of Interpretating the Qur'an", (Ph.D Dissertation, McGill University, 2001), 150.

16 M. Amin Abdullah, "Pendekatan Hermeneutik dalam Studi Fatwa-fatwa Keagamaan," kata pengantar dalam Atas Nama Tuhan: Dari Fikih Otoriter ke Fikih Otoritatif, karya Khaled Abou el-Fadl (Jakarta: Serambi, 2003), xi-xiii. 
penggagas tafsir kontekstual, Fazlur Rahman, mengakui adanya makna yang objektif, dengan menggunakan pembacaan sosio-historis ayat al-Qur'ān. ${ }^{17}$

Meski demikian, pemikiran tokoh Tekstulis mempunyai landasan yang kuat. Mereka mengacu pada pola penafsiran salaf al-săliḥ. ${ }^{18}$ Penafsiran kaum terdahulu (the Righteous Predecessors) dipandang bersifat normatif, statis, dan universal, sehingga setiap produk tafsir generasi berikutnya mesti disandarkan pada pemikiran mereka. Inilah yang menyebabkan kelompok tekstualis melakukan penafsiran secara literal dan tidak melakukan kontekstualisasi teks al-Qur'ān dan Sunnah, dan hanya mendasarkan pada literatur hadis. Produk tafsir klasik, yang didasarkan pada analisis bahasa dan metode periwayatan, dipandang akan selalu relevan pada setiap tempat dan kondisi. ${ }^{19}$

Berdasarkan pandangan kontekstual, makna teks dapat saja dipahami beragam oleh umat Islam, karena dipengaruhi oleh situasi sosio-historis penafsir. Makna teks harus didasarkan pada analisis konteks teks dan juga mempertimbangkan situasi dan kondisi masyarakat pada saat teks hendak ditafsirkan. Sedangkan, kalangan tekstual berupaya menjadikan teks sebagai poros penafsiran, dan cenderung mengabaikan unsur sosio-historis (ketika wahyu diturunkan dan ditafsirkan). Berbeda dengan tokoh kontekstual, mereka menjadikan konteks sebagai basis utama penafsiran.

\section{Identifikasi Sosio-Historis: Antara Asbāb al-Nuzāl Mikro dan Makro}

Pembacaan konteks sosio-historis, menggunakan riwayat asbāb al-nuz $\bar{l}$ adalah suatu kemestian ketika menafsirkan al-Qur'ān. ${ }^{20}$ Pada dasarnya, tokoh tekstual dan kontekstual juga menggunakan riwayat asbāb al-nuzūl untuk

${ }^{17}$ Pemikiran Fazlur Rahman, nampaknya terpengaruh oleh mazhab objektivitas (objectivity school) yang digagas oleh E. Betti. Berbeda dengan E. Betti, makna yang objektif bagi Rahman tidak diperoleh dari pikiran pengarang, tapi dapat dilakukan dengan menggali dimensi sosio-historis, karena teks pada dasarnya merupakan respons atas situasi tersebut. Fazlur Rahman, Islam and Modernity, 8.

${ }^{18}$ Al-Salāf al-Sălih adalah komunitas Muslim yang hidup pada masa awal Islam,

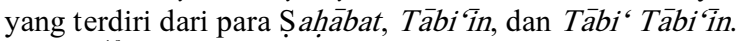

${ }^{19}$ Lihat, Tariq Ramadhan, Western Muslims and The Future of Islam (New York: Oxford University Press, 2004), 25. Baca juga, Adis Duderija, "Islamic Groups and their World-views and Identities: Neo-Traditional Salafis and Progressive Muslims," Arab Law Quarterly 21 (2007): 339-360: 344-346.

${ }^{20}$ Asbāb al-Nuzūl adalah suatu peristiwa atau kejadian yang menjadi latar belakang turunnya ayat al-Qur'an seperti adanya pertanyaan yang ditujukan kepada Nabi Muhammad saw dengan maksud mengetahui hukum syariat, ataupun penjelasan terkait perkara keagamaan. Peristiwa dan kejadian tersebut dinamakan Asbāb al-Nuzūl. Lihat: Muhammad 'Alì aṣ-Ṣābūnì, al-Ṭibyān fì 'Ulüm al-Qur'ān, 24. 
menganalisis teks ayat, tapi intensitas dan pengaruhnya dalam produksi makna mempunyai perbedaan yang signifikan. Kelompok tekstual membatasi penggunaan asbāb al-nuzāl pada riwayat hadis yang terbukti sahih dengan rantai sanad sebagai standar diterima atau ditolaknya sebuah riwayat. Imam al-Wāhidi (w. 427 h) menyebutkan bahwa asbāb al-nuzūl haruslah berdasarkan pada riwayat yang sahih dan pendengaran ( $\operatorname{sim}^{-}$) dari orang yang menyaksikan langsung penurunan wahyu. ${ }^{21}$ asbāb al-nuzūl tidak dibenarkan berasal dari ra'yu (pikiran). Para ulama sepakat bahwa riwayat tanpa sanad sama sekali tertolak. ${ }^{22}$ Dalam tradisi klasik, penelusuran konteks sosio-historis al-Qur'ān dengan menggunakan telaah periwayatan dikenal dengan istilah asbāb al-nuzūl mikro. ${ }^{23}$

Telaah konteks pewahyuan, sebagaimana digunakan dalam tafsir klasik, dinilai terlampau rigid, stagnan, dan tidak responsif terhadap perkembangan zaman. Padahal, al-Qur'ān tidak saja petunjuk bagi masyarakat Arab, tapi pedoman bagi seluruh umat manusia pada setiap waktu dan tempat. Itulah sebabnya, sarjana kontemporer berupaya memperluas ruang kajian asbāb alnuzūl. Jika ulama klasik hanya membatasi asbāb al-nuzūl pada riwayat yang dianggap sahih, yang bersifat simā', tapi sarjana kontemporer, selain menggunakan riwayat yang terpercaya, juga menggali konteks sosio-historis masyarakat Arab pada saat al-Qur'ān diturunkan. ${ }^{24}$

Lewat kajian sosio-historis, kelompok kontekstual berupaya menelusuri maksud dan tujuan wahyu, yang disebut juga nilai ideal-ethics al-Qur'ān. Tokoh kontekstual tidak hanya terpaku pada riwayat asbāb al-nuzūl semata, tapi menganalisis secara mendalam setting sosio-historis masyarakat Arab dengan bantuan literatur sejarah, keterangan dari para șạăbat, ataupun periwayatan hadis yang menjelaskan kondisi pada saat wahyu diturunkan. Perluasan wacana

21 Al-Wāhịidi, Asbāa al-Nuzūl al-Qur'ān: Beirut: Dār al-Kutub al-'Ilmiyyah, 1991), 10.

22 'Abd Allāh'Uthmān al-Sālimī al-'Utmī, Ghāyah al-Ma'mūl fì al-Ta'Tiqàt 'alà al-Sahịh al-Musnad min Asbāb al-Nuzūl (Tanpa Tempat: Șanā' al-Aṣriyyah, Tanpa Tahun), 11.

${ }^{23}$ Konteks mikro al-Qur'an terdiri dari sejarah yang spesifik dan terdekat, sebagaimana yang terdapat dalam teks al-Qur'an. Hal ini sebagaimana tercatat dalam literaratur klasik Asbāb al-Nuzūl. Lihat: Taufik Adnan Amal dan Samsu Rizal Panggabean, Approaches to the Qur'an in Contemporary Indonesia, (ed) Abdullah Saeed (Oxford: Oxford University Press, 2005), 122.

24 Barbara Strowasser mengemukakan bahwa identifikasi makna ayat berdasarkan konteks penurunan wahyu pada abad ke-VII $\mathrm{H}$ telah banyak dilakukan sarjana kontemporer, khususnya mereka yang terdidik di universitas Barat. Barbara Strowasser, "The Qur' an and Its Meaning” The Arab Studies Journal 3, 1 (1995): 4-8. 
asbāb al-nuzūl, yang dilakukan oleh kalangan kontekstualis, disebut sebagai asbāb al-nuzūl makro. ${ }^{25}$

Dengan demikian, kajian konteks pewahyuan al-Qur'ān oleh kalangan tekstual hanya terbatas pada metode periwayatan asbāb al-nuzūl, yang sahih dan bersifat simāi $\bar{i}$. Dalam proses penarikan makna, latar belakang ayat tidak banyak mempengaruhi produksi makna al-Qur'ān. Berbeda dengan pandangan tersebut, kelompok kontekstual melakukan perluasan asbāb al-nuzūl dengan menganalisis konteks sosio-historis pewahyuan, baik adat, tradisi, dan kondisi masyarakat Arab dengan bantuan literatur sejarah, hadis, dan perjalanan Nabi Muhammad saw.

\section{Penarikan Legal-ethics al-Qur'ān: Respons Terhadap Perubahan Sosial}

Tujuan pewahyuan al-Qur'ān adalah menunjuki umat manusia pada setiap tempat dan waktu. Meskipun objek al-Qur'ān pada abad ke-VII hijriah adalah umat Islam pada masa lampau, tapi dinamika masyarakat selalu berubahubah sesuai dengan perkembangan zaman. Umat Islam menghadapi berbagai tantangan di tengah gencarnya arus globalisasi, sedangkan teks al-Qur'ān tidak lagi menerima modifikasi, dan telah menjadi corpus resmi. Al-Qur'ān tidak akan bermakna, jika masalah yang membelenggu umatnya tidak dapat teratasi. Dewasa ini, umat Islam yang terdiri dari berbagai mazhab dan aliran berupaya mengelaborasi teks al-Qur'ān agar selalu relevan dengan kondisi masyarakat.

Tokoh tekstual berpandangan bahwa umat Islam seharusnya merujuk pada ketentuan al-Qur'ān, karena ia diturunkan untuk menjawab dan mengatasi berbagai persoalan yang mendera umatnya. Islam adalah agama yang paling rasional dibandingkan agama lainnya, sehingga antara nilai ideal al-Qur'ān dan perkembangan sosial dapat disatukan dengan merujuk pada ketentuan al-

${ }^{25}$ Konteks makro adalah latar belakang historis masyarakat Arab sebelum alQur'an dan selama pewahyuan, yang mencakup konteks masyarakat, agama, tradisi, dan pranata jazirah Arab, termasuk Mekah dan Madinah. Telaah Asbāb al-Nuzūl makro dapat diidentifikasi melalui penyebutan nama dan kejadian yang disebutkan dalam al-Qur'an. Isyarat tersebut digunakan sebagai alat untuk melacak konteks pewahyuan al-Qur'an. Perang Badar misalnya terdapat dalam [Ali 'Imrān: 13, 123; al-Anfāl: 7,9, 11-15, 17, 4244, 67], Perang Uhud [Ali 'Imrān: 155-174], dan lainnya. Latar belakang sejarah digunakan untuk menghubungkan suatu kejadian dengan ayat yang spesifik. Data historis al-Qur'an masih terbatas dan pada umumnya banyak ditemukan berkaitan dengan wahyu pada periode Madinah, sedangkan pada periode Mekah adalah sangat terbatas, dan tidak jelas. Taufik Adnan Amal dan Syamsu Rizal Panggabean, $A$ Contextual Approach to the Qur'an, 122, 117-188. Untuk melacak hubungan antara ayat yang bersifat kasuistik dapat dilihat Al-Wāhidi, Asbāb al-Nuzūl al-Qur'ān. 
Qur'ān. ${ }^{26}$ Walaupun, al-Qur'ān turun pada abad ke-VII hijriah, dengan objek masyarakat Arab pada masa itu, tapi ia bersifat universal dan akan selalu relevan dengan berbagai situasi dan kondisi. Transformasi budaya hanya dapat dilakukan dengan merujuk pada teks al-Qur'ān. Kelompok Salafï misalnya terkenal dengan slogan kembali pada al-Qur'ān dan Sunnah. Ayat al-Qur'ān diyakini pula bersifat statis, normatif, sehingga hukumnya bersifat final, dan tidak mengalami perubahan. Pernyataan tersebut didukung oleh sejumlah ayat, yang menyatakan bahwa al-Qur'ān telah sempurna. ${ }^{27}$

Berbeda dengan paradigma di atas, tokoh kontekstual meyakini bahwa persoalan sosial dapat diselesaikan melalui proses dialektik antara teks alQur'ān dan perkembangan masyarakat. ${ }^{28}$ Pembacaan secara literal (philological approach) dinilai tidak dapat mengakomodir kebutuhan masyarakat. Walaupun teks al-Qur'ān telah final dan menjadi corpus resmi umat Islam, tapi ia harus selalu relevan dengan perkembangan masyarakat. Oleh sebab itu, perlu kajian spesifik mengenai kondisi sosial masyarakat dan konteks sosio-historis penurunan wahyu. Pengabaian situasi sosial dapat mengakibatkan produk hukum yang kontra produktif dan tidak sesuai dengan kebutuhan masyarakat. ${ }^{29}$

Ada beberapa tahap yang mesti dilewati untuk melakukan proses dialektika. Seorang mufasir hendaknya melakukan elaborasi sosio-historis, yang terdiri dari situasi sosial, budaya, kultur, dan tradisi masyarakat Arab ketika al-

${ }^{26}$ Massimo Campanini, The Qur'an: Modern Muslim Interpretations, terj. Caroline Higgitt (London dan New York: Routledge, 2011), 8-10.

${ }^{27}$ Berdasarkan penelusuran terhadap tiga tafsir Salafi, yaitu Taysir al-Karim alRahmān karya Muhammad Nāṣir al-Sa'dì (1889-1956), Adwā' al-Bayān karya Muḥammad Amīn al-Shinqītī (1907-1973), dan Aysār al-Tafsìr oleh Abū Bakar Jabīr alJaziri (1921), ditemukan bahwa kecenderungan tafsir Salafi adalah bersifat literal (wooden literalism), dan menutup berbagai kemungkinan makna. Ini disebabkan oleh generalitas pembacaan ayat, dan al-Qur'an dianggap sebagai language, bukan sebagai discourse. Lihat: Izza Rohman, "Salafi Tafsirs: Textualist or Authoritarian," Qur'an and Hadith Academic Society 1, 2 (2012): 197-213: 201-206. Isyarat terkait kesempurnaan ajaran Islam terdapat dalam Q.S al-Mā'idah [5]: 3. Q.S al-An'ām [6]: 115.

${ }^{28}$ Kecenderungan ini dapat dilihat dalam berbagai karya kelompok Muslim Progresif yang berupaya menghubungkan antara konteks pewahyuan dengan konteks masyarakat kontemporer saat ini, dengan memperhatikan kondisi sosial dan nilai yang berkembang, seperti pluralisme agama (religious pluralism), kesetaraan gender (gender equality), dan keadilan (justice). Lihat: Clinton Bennett, Interpretating the Qur'an: A Guide for the Uninitiated. Ingrid Mattson, The Story of the Qur'an: Its History and Place in Muslim Life (Oxford: Blackwell Publishing, 2008). Omid Safi (ed), Progressive Muslims.

${ }^{29}$ Abdullah Ahmed An-Na'im, Toward an Islamic Reformation: Civil Liberties, Human Rights, and International Law (New York: Syracuse University Press, 1990), 182-187. 
Qur'ān diturunkan. ${ }^{30}$ Pembacaan konteks penurunan al-Qur'ān secara spesifik dikenal dengan istilah asbāb al-nuzūl makro dengan menggunakan sejumlah literatur hadis (riwayat asbāb al-nuzūl mikro), sejarah kenabian, dan keterangan lainnya yang berkaitan dengan situasi penurunan wahyu. ${ }^{31}$ Dengan mengetahui setting masyarakat Arab dapat diketahui pula kandungan legal-ethics al-Qur'ān. Pada tahap selanjutnya, kandungan legal-ethics itulah yang akan dihubungkan, dengan memperhatikan azas persamaan antara tujuan al-Qur'ān dan kondisi sosial masyarakat kontemporer.

Berdasarkan paparan di atas dapat disimpulkan bahwa kelompok tekstual menyelesaikan persoalan sosial dengan menarik ketentuan legal spesifik ayat al-Qur'ān, kemudian ditransfer pada konteks kontemporer. Dengan kata lain, ayat al-Qur'ān dianggap universal, spesifik, statis, normatif, sehingga akan senantiasa relevan diterapkan pada setiap situasi dan kondisi apapun. Produksi makna ayat berdasarkan pada analisis kebahasaan, dan didukung oleh periwayatan hadis, ataupun penafsiran Salaf al-Salih. Pada sisi lain, tokoh kontekstual melakukan proses dialektika dalam penafsiran al-Qur'ān dengan mendialogkan konteks sosio-historis teks dan perkembangan masyarakat. Analisis tersebut menggunakan perangkat riwayat asbāb al-nuzūl, literatur hadis, sejarah ke-Nabi-an. Melalui proses seperti inilah permasalahan sosial dapat teratasi.

\section{Interfaith Dialogue: Sikap terhadap Umat Beragama}

Kajian terhadap penafsiran al-Sa'di mengenai relasi Muslim dan nonMuslim setidaknya perlu didahului oleh penjabaran makna pluralisme agama. Ini digunakan sebagai standar untuk menentukan sikap yang seharusnya (the right attitude) dilakukan oleh seorang Muslim kepada non-Muslim. Pada tahap selanjutnya akan dijelaskan pandangan toleransi terhadap non-Muslim ( $A$ hl alKitāb) dalam perspektif al-Sa'di dengan menganalisis metodologi penafsiran yang digunakannya. Produk tafsir tersebut kemudian dikaji secara analitis dan kritis melalui pendekatan sosio-historis ataupun hermeneutika kontekstual yang

${ }^{30}$ Adis Duderija, "The Interpretational Implications of Progressive Muslims' Qur'an and Sunna Manhāj in Relation to their Formulation of a Normative Muslima Construct," 416. Muhammad Abdel Haleem melakukan identifikasi pada ayat perang dalam al-Qur'an. Ia mengatakan bahwa ayat al-Qur'an mesti dibaca berdasarkan konteksnya. Jika al-Qur'an dilepaskan dari konteksnya, maka ayat al-Qur'an dapat saja disalah pahami, bahkan bertolak belakang dengan spirit al-Qur'an. Muhammad Abdel Haleem, Understanding the Qur'an: Themes and Styles (London dan New York: I.B Tauris, 2011), 215, 61-72.

\footnotetext{
${ }^{31}$ Clinton Bennett, Interpreting the Qur'an: A Guide for the Uninitiated, 21-22.
} 
dirumuskan oleh Abdullah Saeed dan juga metode maqāsiḍ al-shari ‘ ${ }^{a} h$ rumusan Jasser Auda.

\section{Defenisi dan Sikap terhadap "Pluralisme Agama”}

Mengutip Diana Eck dalam A New Religious America, Amir Hussain menyebutkan bahwa setidaknya terdapat beberapa faktor untuk mendefenisikan makna "pluralisme". Pluralisme tidak dapat diartikan sebagai keanekaragaman semata. Ia adalah keterlibatan aktif berbagai elemen masyarakat yang berasal dari berbagai latar belakang etnis dan agama. Pluralisme tidak hanya berperilaku toleran kepada pemeluk agama lainnya, tapi juga adanya sikap pengertian satu dengan lainnya. Konsep ini juga tidak dapat diartikan sebagai relativisme. Melainkan, pluralisme mengharuskan adanya pandangan yang pluralis untuk menghadapi berbagai perbedaan. ${ }^{32}$ Dengan demikian, pluralisme agama dapat diartikan sebagai bentuk pengakuan terhadap keanekaragaman dan berpindah menuju proposal teoritis mengenai pluralisme yang dapat berakhir pada parenilisme (sebagian bentuk pluralisme dapat juga disebut universalisme). ${ }^{33}$

Kajian Pluralisme agama memang tidak banyak ditemukan dalam literatur tafsir klasik. Tema ini adalah pemikiran yang dimunculkan oleh para tokoh Muslim kontemporer. Meski demikian, paham pluralisme juga didasarkan pada al-Qur'ān itu sendiri karena ditemukan sejumlah ayat al-Qur'ān yang memerintahkan agar berlaku secara toleran dan tidak memaksakan kebenaran subjektif kepada pihak lain. ${ }^{34}$ Mircea Eliade menyebutkan bahwa ketika manusia memasuki dimensi duniawi, maka ia secara otomatis telah menjadi homo religiosus, yaitu hidup dengan aneka perbedaan baik agama, kultur, dan tradisi. $^{35}$ Dengan demikian, pluralitas adalah suatu keniscayaan yang tak mungkin dihindari.

32 Amir Hussain, "Muslims, Pluralism, and Interfaith Dialogue" dalam Progressive Muslims, (ed) Omid Safi (Oxford: One World Publication, 2008), 251-252.

${ }^{33}$ Sajjad H Rizvi, "A Primodial e pluribus unum?: Exegeses on Q. 2:213 and Contemporary Muslim Discourse on Religious Pluralism", Journal of Quranic Studies 6: 1 (2004): 21-42: 22-23.

${ }^{34}$ Sajjad H Rizvi, "A Primodial e pluribus unum?: Exegeses on Q. 2:213 and Contemporary Muslim Discourse on Religious Pluralism", 21-42: 34-36. .

${ }^{35}$ Mircea Eliade, The Sacred and the Profane: The Nature of Religion (New York: harper dan Row, 1961), 204. Lihat juga Sajjad H. Rizvi, "A Primordial e pluribus unum? Exegeses on Q. 2:213 and Contemporary Muslim Discourses on Religious Pluralism," Journal of Qur'anic Studies, 6:1 (2004): 21-42: 23. 
Muqsith al-Ghazali menyebutkan tiga sikap yang merepresentasikan perilaku beragama, yaitu: pertama, sikap eksklusif. Agama yang benar hanyalah agama yang dianutnya karena kebenaran dan keselamatan hanya akan diperoleh dengan mengikuti jalan yang telah ditetapkan oleh agama tersebut. Kedua, sikap inklusif. Paradigma ini menyatakan tentang pentingnya memberikan toleransi terhadap orang lain, terlebih umat lain yang mendasarkan pandangan keagamaannya kepada sikap tunduk dan patuh hanya kepada Tuhan. NonMuslim dianggap berada pada jalan yang benar selama yang bersangkutan memiliki ketulusan dan ketundukan. Ketiga, paradigma pluralis. Pandangan ini menyatakan bahwa setiap agama memiliki jalannya tersendiri. Karena itu, agama tersebut harus dipandang dari sudutnya masing-masing. Dan pihak lain sama sekali tidak berhak untuk menjustifikasi keselamatan umat lainnya. ${ }^{36}$

Berdasarkan pembagian di atas, Mircea Eliade menyebutkan bahwa sikap keagamaan yang dapat menunjang terwujudnya dialog antar umat beragama adalah sikap yang inklusif dan pluralis. ${ }^{37}$ Pendapat yang sama juga dikemukakan oleh sejumlah sarjana dan pemikir Muslim kontemporer. Fathullah Gulen misalnya dalam konteks umat beragama di Turki berupaya menghadirkan pandangan keagamaan yang toleran agar terwujudnya co-existence antar berbagai pemeluk agama. Keadaan ini, menurut Fathullah Gulen, akan dapat segera terwujud apabila dilakukan dengan proses dialog. ${ }^{38}$ Hal yang sama juga dilakukan oleh Farid Esack. Dalam konteks Afrika Selatan, Farid Esack berupaya memperlihatkan kepada kaum Muslim (di Afrika Selatan) bahwa Islam senantiasa menyeru umat manusia agar mengutamakan toleransi dalam menghadapi berbagai perbedaan. ${ }^{39}$ Karena itu, sikap toleran, terbuka, dan senantiasa mengutamakan dialog hendaknya menjadi dasar umat manusia untuk saling berinteraksi dengan umat agama lainnya (non-Muslim).

${ }^{36}$ Abd. Moqsith Ghazali, Argumen Pluralisme Agama, 53-60. Baca Karl Rahner, "Other Religions are Implicit Forms of Our Own Religion" dalam John Lyden (ed), Enduring Issues in Religion (San Diego: Greenhaven Press, 1959), 73.

${ }^{37}$ Mircea Eliade, The Sacred and the Profane: The Nature of Religion (New York: Harper dan Row, 1961), 205-206.

${ }^{38}$ Zeki Saritoprak dan Sidney Griffith, "Fethullah Gulen and the 'People of the Book': A Voice from Turkey for Interfaith Dialogue," The Muslim World, 95, 3 (2005): 329-340.

${ }^{39}$ Farid Esack, Qur'an, Liberation, and Pluralism: An Islamic Perspective if Interreligious Solidarity against Oppression (Oxford: Oneworld, 1998), 207-251. 
Interaksi Umat Beragama: Pandangan Nāṣir al-Sa'dì terhadap non-Muslim ( $A h l$ al-Kitāb)

Nama lengkapnya adalah Abū 'Abd Allāh 'Abd al-Raḥmān ibn Nāṣir Āli Sa'di. Ia dilahirkan pada 12 Muharam (1307-1376 H/ 1887-1956 M) di kota 'Unayzah wilayah Qașīm, Arab Saudi. Ketika berumur sebelas tahun, ia telah hapal al-Qur'ān dan mendalami cabang ilmu al-Qur'ān dari para ulama di 'Unayzah. ${ }^{40}$ Shaykh al-Sa'di adalah salah satu anggota Salafi berkebangsaan Arab yang mengarang tafsir 30 juz lengkap. ${ }^{41}$ Kitab yang dikarangya hampir mencakup semua ranah kajian Islam. ${ }^{42}$ Tafsir Taysīr al-Karīm al-Raḥmān adalah karyanya yang paling populer. Ia juga banyak melakukan tahqiq fiqih mazhab Hanbali. Orientasi kajian al-Sa'di adalah kajian Islam riwayat bukan pemikiran. Itulah sebabnya, tidak ditemukan satupun karyanya yang berisi kajian filsafat Islam. Apalagi, kelompok Salafi umumnya tidak begitu tertarik menggunakan "rasio" secara berlebihan dalam menafsirkan teks keagamaan.

Sejumlah kitab yang dikarang oleh al-Sa'di menunjukkan bahwa ia mengikuti ajaran Salafi. Kecenderungan tersebut bisa dilihat dalam karyanya. Tidak ada satupun ayat sifat yang ditakwil dan ditafsirkan. Bagi kelompok Salafi, ayat sifat perlu dibaca secara tekstual dengan menyerahkan maknaya hanya kepada Allah tanpa dilakukan penakwilan. ${ }^{43}$ Cara ini bertujuan untuk menjaga dan memantapkan akidah umat Islam. ${ }^{44}$ Meski demikian, ia tetap mengunakan kaidah usuliyyah, fiqhiyyah dalam menafsirkan al-Qur'ān. Ia banyak menulis dan mengahapal kitab yang berasal dari mazhab Hanbali karena pada awalnya ia menganut mazhab Hanbali. Kitab pertama yang dikarangnya

${ }^{40}$ Informasi ini bersumber dari keterangan salah seorang murid al-Sa'di. Tidak disebutkan secara jelas nama muridnya. Nāșir al-Sa'đi, Majmū'ah al-Kāmilāh liMu'allifăt 'Abd al-Rahmmān Ibn Nāsir al-Sa'dì Taysìr al-Karìm al-Rahmmān fì Tafsìr Kalām al-Mannān ('Unayzah: Markaz al-Thaqāfì, 1987), juz I, 5.

${ }^{41}$ Izza Rohman, "Salafi Tafsir: Textualist and Authoritarian," Journal of Qur'ān and Hadith Studies 2/1 (2013): 197-213.

42 Adapun karya al-Sa'di adalah: (1) Tafsìr Taysìr al-Karim al-Mannān. (2) Mentahqiq dan mentashih sejumlah kitab fiqih mazhab Hanbali. (3) 'Irshād ' $\overline{\text { la }} \overline{\mathrm{a}}$ alBașā'ir wa al-Albāb [1365]. (4) al-Durrah al-Mukhtasarah fị Maḥāsin al-Islām [1366]. (5) al-Khitab al-'Isriyyah al-Qayyimah (6) al-Qawā'id al-Hisān li-tafsìr al-Qur'ān [1366]. (7) Tanzih al-Din wa Hamlatuhu wa Rijāluhu [1366]. (8) al-Haqq al-Wadih al-Mubin (Sharh Tauhid al-Anbiyā' wa al-Mursalin]. (9) Tauḍị al-Kāfiyyah al-Shāfiyyah (10) Wujūn ai-

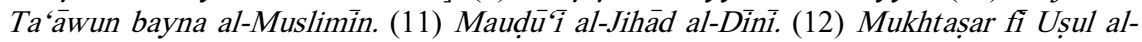
Fiqh. (13) Taysīr al-Latịif al-Mannān fí Khulāsāh Tafsir al-Qur'ān. (14) al-Riyāọ anNädirah.

${ }^{43}$ Ṭahir Mahmūd Muhammad Ya'qūb, Asbāb al-Khata' fì al-Tafsìr (Riyād: Dār Ibn al-Jawzīi, 2004).

${ }^{44}$ Nāṣir al-Sa‘di, Taysīr al-Karīm al-Raḥmān (Kairo: Maktaba Sunna, 2002), 13. 
adalah kitab fiqih. Ia juga mensyarah kitab nazm rajz yang berjumlah sekitar 104 bait secara ringkas. Akan tetapi, al-Sa'di tidak merasa puas dengan karya tersebut. Ia kemudian mengkaji tulisan Ibnu Taymiyyah (w. $728 \mathrm{H}$ ), dan muridnya Ibnu Qayyim (w. $751 \mathrm{H}$ ). Dari bacaan tersebut, ia mendapat banyak pengetahuan dari kitab yang dikarang oleh dua ulama Salafi tersebut.

Kecenderungan tersebut dapat dilihat dalam tafsirnya yang berjudul Taysīr al-Karīm al-Raḥmān fï Kalām al-Mannān mengenai hubungan antar umat beragama. Ayat al-Qur'ān yang seringkali dijadikan dasar justifikasi untuk menilai non-Muslim (terutama Yahudi dan Nasrani) sebagai musuh (enemy) adalah QS al-Baqarah [2]: 120 dan QS al-Mā'idah [5]: 51. Ayat ini berbicara mengenai ketidakrelaan Ahl al-Kitāb (Yahudi dan Nasrani) kepada umat Islam, dan pengangkatan non-Muslim sebagai pemimpin (awliya').

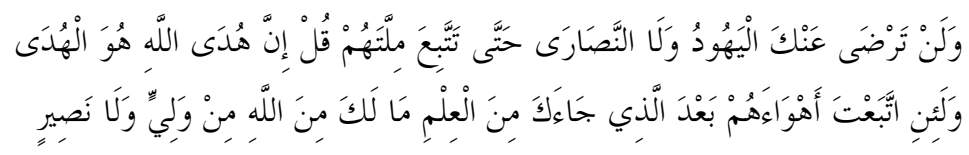

“Orang-orang Yahudi dan Nasrani tidak akan senang kepadamu hingga kamu mengikuti agama mereka. Katakanlah, 'sesungguhnya petunjuk Allah itulah petunjuk (yang benar).' Dan jika kamu mengikuti kemauan mereka setelah pengetahuan datang kepadamu, maka Allah tidak lagi menjadi penolong dan pelindung bagimu." QS al-Baqarah [2]: 120

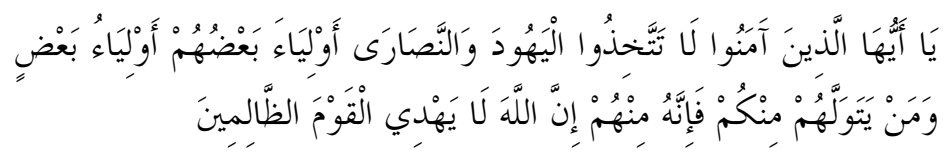

"Hai orang-orang yang beriman, janganlah kamu mengambil orang Yahudi dan Nasrani menjadi awliyā' (mu), sebagian mereka adalah awliyā' bagi sebagian yang lain. Siapa di antara kamu mengambil mereka menjadi wali, maka sesungguhnya orang itu termasuk golongan mereka. Sesungguhnya Allah tidak memberikan petunjuk kepada orang-orang yang zalim.” QS alMā'idah [5]: 51.

Menafsirkan ayat pertama, al-Sa'di menjelaskan bahwa Yahudi dan Nasrani tidak akan rela kecuali setelah umat Islam mengikuti agama mereka. Ini disebabkan Yahudi dan Nasrani selalu menyeru kepada agama yang mereka anut. Ajaran tersebut dianggap sebagai petunjuk. Karena itu, Allah memerintahkan kepada umat Islam supaya menyatakan bahwa apa yang telah 
diutus kepada umat Islam adalah petunjuk. ${ }^{45}$ Sedangkan ajaran yang dianut oleh Yahudi dan Nasrani adalah hawa nafsu belaka. Pendapat al-Sa'di tersebut didasarkannya pada firman Allah: "Dan sesungguhnya jika kamu mengikuti keinginan mereka setelah pengetahuan datang kepadamu, maka Allah tidak lagi menjadi penolong dan pelindung bagimu'. Menurut al-Sa'di, ayat ini sekaligus melarang seorang Muslim agar tidak mengikuti keinginan kaum Yahudi dan Nasrani dan dilarang menyerupai mereka dalam persoalan agama. Pada dasarnya, meskipun ayat ini hanya ditujukan kepada Nabi Muhammad saw, tapi menurut al-Sa'di, khitab ayat ini juga termasuk umat Nabi Muhammad saw. Ini disebabkan makna itu didasarkan oleh keumuman lafaz dan bukan kekhususan sabab (al- 'ibrah bi-al- 'umūm al-lafaz lā bi-khușus al-sabāb). ${ }^{46}$

Pendapat al-Sa'di tersebut sejalan dengan penafsiran Ibnu Kathï. Menurutnya, Yahudi dan Nasrani tidak akan rela terhadap Muhammad. Padahal, petunjuk yang Allah berikan kepada Nabi Muhammad saw adalah sebenarbenarnya petunjuk. Petunjuk tersebut adalah agama yang benar, lurus, dan sempurna. Menurut Ibnu Kathïr, ayat ini adalah peringatan sekaligus ancaman kepada umat Islam supaya tidak mengikuti jalan kaum Yahudi dan Nasrani. Ini disebabkan mereka menentang Nabi Muhammad saw dan para pengikutnya. Meskipun objek ayat ini ditujukan kepada Nabi Muhammad saw tapi juga diarahkan kepada seluruh umat Nabi Muhammad saw. ${ }^{47}$ Pendapat Ibnu Kathïr ini lemah karena tidak dilakukannya spesifikasi penafsiran. Ia tidak menyebutkan siapakah golongan Yahudi dan Nasrani yang dimaksud.

Pandangan Ibnu Kathir tersebut dinilai terlalu umum. Pendapat yang agak spesifik dikemukakan oleh Nawawi al-Jawi. Menurutnya, orang Yahudi dan Nasrani yang tidak akan rela kepada Nabi Muhammad saw itu adalah Yahudi Madinah dan Nasrani Najran. ${ }^{48}$ Spesifikasi ayat di atas juga disebutkan oleh Ibnu 'Abbās. Kaum Yahudi dan Nasrani yang disebutkan pada ayat ini adalah Yahudi Madinah dan Nasrani Najran. Dua kelompok ini tidak akan rela terhadap Nabi Muhammad saw hingga ia mengikuti agama dan kiblat mereka. ${ }^{49}$

${ }^{45}$ Nāșir al-Sa'di, Taysīr al-Karīm al-Rahmān, 65.

${ }^{46}{ }^{N a ̄ s ̣ i r ~ a l-S a ' d i, ~ T a y s i ̀ r ~ a l-K a r i ̀ m ~ a l-R a h ̣ m a ̄ n, ~} 65$.

${ }^{47}$ Ibnu Kathìr, Tafsìr al-Qur'ān al-Azìm (Beirut: Dār Kutub al-'Ilmiyyah, 1997), juz I, 281. Penafsiran yang sama juga diungkapkan dalam Tafsìr al-Mizān. Lihat Muhammad Husayn Tabātabā'i, al-Mizān fì Tafsìir al-Qur'ān (Beirut: Mu'assah al-'Alā [i-al-Matbūât 1997), juz I, 261. Baca juga Mutawalli Sha'rawi, Tafsirir Sha'rawī, 563.

${ }^{48}$ Nawawi al-Jawī, Marah Labìdh (Indonesia: Dār al-Ihyā', tanpa tahun), juz I, 10.

${ }^{49}$ Ibnu 'Abbās, Tanwìr al-Miqbās (Beirut: Dār al-Fikr, 1995), 16. Al-Khāzin, Tafsìr al-Khāzin (Beirut: Dār al-Kutub al-'Ilmiyyah, 2004), 74-75. 
Jika mengikuti pendapat Nawawī al-Jawi dan Ibnu 'Abbās di atas, maka ayat tersebut tidak berlaku secara umum. Adapun objek ayat ini adalah orang Yahudi Madinah dan Nasrani Najran. Nawawi al-Jawi menyebutkan bahwa term “ "anka” dalam ayat itu menegaskan bahwa keberatan dan ketidakrelaan Yahudi Madinah dan Nasrani Najran itu ditujukan hanya kepada Muhammad dan bukan kepada umatnya. Itulah sebabnya al-Qur'ān menggunakan kata" 'anka” bukan kata " 'ankum". 50

Jika dianalisis lebih lanjut, al-Sa'di tidak menyebutkan konteks ayat berupa asbāb al-nuzūl. Analisis kondisi masyarakat dan dalam situasi apa, kepada siapa ayat ini ditujukan juga tidak disebutkan. Padahal, apabila dirujuk asbāb al-nuzūl ayat, maka objeknya ditujukan pada sebagian kelompok Yahudi dan Nasrani yang tidak rela kepada umat Islam. Ayat ini tidak ditujukan kepada seluruh umat Nasrani dan Yahudi. Objek ayat adalah kelompok Yahudi Madinah dan Nasrani Najran sebagaimana disebutkan oleh Nawawi al-Jawi dan Ibnu 'Abbās. Tetapi, apabila pembacaan tersebut dijadikan penafsiran yang bersifat baku, maka penafsiran seperti ini tidak akan menunjang terwujudnya dialog antar agama. Kalaupun, terjadi dialog, maka dialog tersebut akan bersifat semu semata. Ini dikarenakan non-Muslim (Yahudi dan Nasrani) dianggap sebagai kelompok yang tidak mau mengikuti dialog dan mereka selalu berupaya agar umat Islam mengikuti agama mereka (Yahudi dan Nasrani).

Jika ditelaah sejumlah literatur asbāb al-nuzūl, dapat ditemukan latar belakang ayat ini secara spesifik. Al-Wāhịi dalam Asbāb al-Nuzūl al-Qur'ān menyebutkan bahwa ayat ini berkenaan dengan arah kiblat. Yahudi Madinah dan Nasrani Najran berharap agar Nabi shalat menghadap kiblat mereka, ketika Allah memindahkan kiblat ke Ka'bah, tapi mereka enggan melakukannya. ${ }^{51}$ Ibnu 'Ațiyyah menyebutkan bahwa asbāb al-nuzūl ayat ini berkenaan dengan sekelompok orang dari golongan Yahudi dan Nasrani yang meminta kepada Nabi Muhammad saw agar melakukan perdamaian. Mereka kemudian menjanjikan kepada Rasul untuk mentaatinya. Akan tetapi, Allah Maha mengetahui bahwa perjanjian tersebut tidak akan mendatangkan manfaat karena mereka hanya ingin menipu Rasul saja. ${ }^{52}$

Menurut Tanțāwī Jawhari kalimat "Hingga engkau mengikuti agama (millah)" hanyalah kināyah saja yang menunjukkan keterputusasaan bahwa

${ }^{50}$ Nawawī al-Jawī, Marah Labìdh, juz I, 10. 1991), 43.

${ }^{51}$ Aḥmad al-Wāhiđīi, Asbāa al-Nuzūl al-Qur'ān (Beirut: Dār al-Kutub 'Ilmiyyah, 128-129.

${ }^{52}$ Ibnu 'Ațiyyah al-Andalūsì, Muḥarrar al-Wajīz (Qāhirah: Dār Ḥadith, 2006), 
golongan Yahudi dan Nasrani tidak mungkin (mustahil) mengikuti agama Islam. ${ }^{53}$ Menurut Mutawalli Sha'rawi, golongan Yahudi dan Nasrani tidak akan mau berpaling mengikuti agama Muhammad. Mereka hanya ingin menipu dan merayu Muhammad agar mengikuti agama mereka. Ini disebabkan mereka (Yahudi dan Nasrani) telah mengubah kitab yang berisi ajaran yang telah diajarkan kepada mereka. ${ }^{54}$

Selain QS al-Baqarah [2]: 120, penafsiran ayat QS al-Mä'idah [5]: 51 yang dikemukakan oleh al-Sa'di juga menjadi dasar utama untuk menilai nonMuslim sebagai musuh. Pengangkatan non-Muslim menjadi awliyā' adalah sama saja dengan mengikuti langkah mereka. Apalagi, non-Muslim dinilai akan senantiasa memusuhi umat Islam. Para $A$ hl al-Kitäb akan membuka rahasia dan akan melemahkan kekuasaan kaum Muslimin.

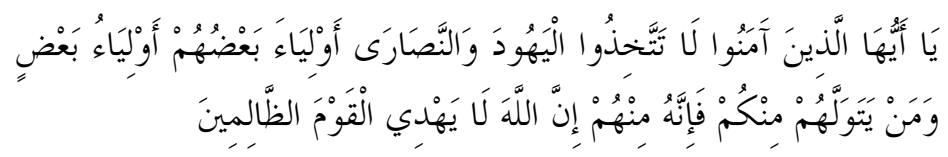

"Hai orang-orang yang beriman, janganlah kamu mengambil orang Yahudi dan Nasrani menjadi awliyā' (mu), sebagian mereka adalah awliyā' bagi sebagian yang lain. Siapa di antara kamu mengambil mereka menjadi pemimpin, maka sesungguhnya orang itu termasuk golongan mereka. Sesungguhnya Allah tidak memberikan petunjuk kepada orangorang yang zalim.” QS al-Mā'idah [5]: 51

Menurut al-Sa'di, penjelasan Allah swt mengenai sifat buruk orang Yahudi dan Nasrani adalah petunjuk bagi umat Islam supaya tidak mengangkat non-Muslim (Yahudi dan Nasrani) sebagai awliyā'. Ini disebabkan Yahudi dan Nasrani hanya menjadi awliyā' bagi kelompoknya masing-masing dan mereka akan bekerjasama melawan orang yang tidak seagama dengan mereka. Karena itu, umat Islam hendaknya tidak mengangkat non-Muslim sebagai penolong (awliyā') karena Yahudi dan Nasrani adalah musuh umat Islam yang

${ }^{53}$ Țantāwì Jawharì, al-Jawāhir fỉ Tafsìr al-Qur'ān, juz I, Pendapat yang sama juga dikemukakan oleh Ibnu 'Ashūr. Ia menambahkan bahwa digunakannya kata 'lan' dalam ayat ini (yang ditujukan pada kelompok Yahudi) menunjukkan ketidakmungkinan mereka untuk mengikuti agama (sharī at) Islam baik pada masa hidup Nabi Muhammad saw, masa yang akan datang dan selama hidup mereka. Ibnu 'Ashūr, Tafsìr Ibnu 'Ashūr, juz I, 120. Lihat juga Zamakhsharì, Tafsìr al-Kashshäf (Beirut: Maktabah 'Ubaykān, 1998), juz I, 316.

${ }^{54}$ Mutawalli Sha'rawi, Tafsìr Sha'rawī, 560-564. 
sebenarnya. Mereka tidak mempedulikan penderitaan umat Islam bahkan tidak menghemat energi sedikitpun dengan tujuan untuk menyesatkan. Siapa yang mengangkat non-Muslim sebagai wali, maka ia adalah satu golongan dengan mereka. $^{55}$

Pendapat al-Sa'di tersebut juga didasarkan pada firman Allah: "Siapa di antara kamu yang mengambil non-muslim menjadi pemimpin maka sesungguhnya orang itu termasuk golongan mereka." Pengangkatan non-Muslim menjadi pemimpin secara otomatis menuntut perpindahan kepada agama mereka. Loyalitas yang sedikit akan mendorong kepada yang banyak, lalu fase demi fase seorang hamba akan menjadi satu dengan mereka. "Sesungguhnya Allah tidak memberi petunjuk kepada orang yang zalim”. Apabila kamu memberikan bukti kebenaran Islam kepada non-Muslim, sungguh mereka tidak akan mengikuti dan mentaatimu. ${ }^{56}$

Pendapat al-Sa'di di atas menyerupai penafsiran yang dikemukakan oleh sejumlah mufasir. 'Aid al-Qarni menjelaskan bahwa Allah memerintahkan kepada umat Islam supaya tidak menjadikan Yahudi dan Nasrani sebagai sekutu dan penolong dalam hal keimanan. Perintah ini disebabkan mereka akan selalu menentang orang Islam. Dua kelompok ini akan selalu berupaya agar umat Islam mengikuti langkah mereka. ${ }^{57}$ Pendapat yang sama juga dikemukakan oleh Ibnu 'Atiyah. Menurutnya, ayat ini adalah bentuk larangan kepada umat Islam agar tidak menjadikan Yahudi dan Nasrani sebagai penolong dan sekutu selamanya. Orang yang banyak bergaul dengan dua kelompok ini, maka ia termasuk golongan mereka. Meski demikian, dalam proses jual beli diperbolehkan dengan kalangan Yahudi dan Nasrani. Ini disebabkan Nabi Muhammad saw pernah menggadaikan pakaiannya kepada seorang Yahudi ataupun Nasrani. ${ }^{58}$

Selain ayat di atas, terdapat QS Ali 'Imrān [3]: 28 yang juga melarang umat Islam ber-muwālah dan meminta bantuan kepada kaum kafir. Menurut alSa'di, siapapun yang melakukan perbuatan tersebut, maka terlepaslah ia dari pertolongan Allah, sebagaimana Allah berfirman: "Siapa yang melakukan perbuatan demikian, maka tidak adalah Allah baginya”. Muwālah dengan orang

${ }^{55}$ Nāṣir al-Sa'di, Taysìr al-Karìm al-Rahmmān, 235.

56 Näșir al-Sa'di, Taysìr al-Karim al-Rahmān, 235. Terdapat ayat lain yang memerintahkan umat Islam agar tidak mengangkat $A$ hl al-Kitāb menjadi awliyā', yaitu QS Ali 'Imrān [3]: 28, QS al-Mā'idah [5]: 57, QS al-Mumtahanah [60]: 1, QS Ali 'Imrān [3]: 118, dan QS al-Mujādilah [58]: 22.

57 'Aid al-Qarni, Tafsir al-Muyassar, 117-118.

${ }^{58}$ Ibnu 'Ațiyah, Tafsir Ibnu 'Atiyah, 550-551. 
Kafir tidak dapat disatukan dengan iman karena iman memerintahkan agar bermuwālah dengan Allah, dan para awliyā', sebagaimana disebutkan dalam firman Allah "orang Mukmin dan Mukminat sebagian mereka adalah penolong bagi yang lain". 59

Menurut al-Sa'di, siapa yang ber-muwalah terhadap orang kafir, maka ia bukanlah bagian dari orang Mukmin. Orang tersebut akan menjadi bagian dari orang kafir. Allah berfirman bahwa "siapa yang ber-muwalah dengan mereka, maka ia adalah golongan mereka”. Dalam pandangan al-Sa'di, ayat ini dapat dijadikan dalil agar menjauhi orang kafir, tidak bersahabat, condong, dan percaya kepada mereka. Tidak juga dibolehkan orang kafir berdiam di wilayah orang Muslim serta meminta pertolongan mereka untuk membantu persoalan yang merupakan kemaslahatan bagi orang Muslim. Menafsirkan ayat "kecuali memelihara diri dari sesuatu yang ditakuti dari mereka”, al-Sa“di menyebutkan bahwa apabila kamu takut atas dirimu sendiri, maka diperbolehkan bagimu bermuwalah, jika dapat mencegah terjadinya pertumpahan darah. ${ }^{60}$

Penafsiran yang dikemukakan al-Sa'di pada ayat di atas menunjukkan bahwa Ahl al-Kitāb (Yahudi dan Nasrani) telah dipersepsikan dan dianggap sebagai musuh, berbahaya, dan harus dijauhi. Ini disebabkan mereka tidak akan rela dan senantiasa memusuhi dan merayu umat Islam agar mengikuti agama yang mereka anut. Langkah-langkah yang dilakukan hanyalah bertujuan untuk menjadikan umat Islam patuh dan tunduk kepada ajaran yang mereka yakini. Ahl al-Kitāb tidak mempunyai niat baik kepada umat Islam. Pengangkatan non-Muslim sebagai pemimpin merupakan perilaku yang terlarang karena mereka akan selalu berusaha melemahkan kekuasaan umat Islam. Non-Muslim tidak akan mau menolong orang Mukmin.

Dalam penafsiran di atas terdapat dua kecenderungan yaitu (pertama) kelompok mufasir yang cenderung memperluas dan (kedua) melakukan pembatasan [spesifikasi] makna ayat. Jika ditinjau dari aspek metodologi, maka kelompok pertama [al-Sa'di dan Ibnu Kathïr] menggunakan kaidah "al- 'ibrah bi-al-'umūm al-lafaz là bi-al-khuṣus al-sabab". Adapun kelompok kedua (Nawawi al-Jawi dan Ibnu 'Abbās) menafsirkan nash berdasarkan paradigma “al- 'ibrah bi-al-khuṣuṣ al-sabab lā bi-al- 'umūm al-lafaż'. Kaidah pertama dapat diartikan sebagai bentuk pemahaman nash (teks) dengan mengutamakan generalisasi makna ayat. Adapun kaidah kedua dapat dipahami sebagai bentuk

\footnotetext{
${ }^{59}$ Nāsir al-Sa‘di, Taysìr al-Karìm al-Rahmān, 126-127.

${ }^{60}$ Nāṣir al-Sa'di, Taysìr al-Karìm al-Raḥmān, 126-127.
} 
pembatasan nash berdasarkan konteksnya. Teks harus dipahami berdasarkan konteks dan tidak dapat diperluas keluar dari konteks.

Dari dua paradigma tersebut, jika kaidah pertama digunakan untuk menafsirkan ayat terkait relasi Muslim dan non-Muslim, maka dapat melahirkan penafsiran yang eksklusif dan intoleran terhadap non-Muslim (Ahl al-Kitäb). Ini disebabkan non-Muslim [baik Yahudi maupun Nasrani] telah dipersepsikan dan dinilai secara menyeluruh sebagai kelompok yang tidak akan rela dan ridho dengan Nabi Muhammad pada setiap kondisi dan waktu. Berbeda dengan paradigma kedua yang cenderung membatasi makna hanya pada kelompok tertentu saja. Dengan demikian, tidak semua $A h l$ al-Kitāb dinilai dan dianggap sama. Haruslah ada spesifikasi dan pemilihan di antara komunitas Yahudi dan Nasrani itu sendiri. Pemahaman seperti ini akan membuka peluang munculnya pemahaman yang inklusif dan menumbuhkan persepsi-persepsi positif terhadap non-Muslim ( $A$ hl al-Kitāb).

Generalisasi makna $A h l$ al-Kitāb yang dilakukan al-Sa'di tidaklah tepat karena jika ayat al-Qur'ān dibaca secara menyeluruh maka al-Qur'ān itu sendiri tidak menyamakan seluruh $A h l$ al-Kitäb. Di samping itu, al-Sa'di secara tidak langsung telah mengakui bahwa tidak seluruh Ahl al-Kitāb bersikap menentang umat Islam karena di antara mereka didapati orang yang adil, lurus, dan berperilaku baik sebagaimana terdapat dalam tafsirnya. Ini menunjukkan bahwa al-Sa'di tidak konsisten karena pada satu sisi ia mengakui bahwa Ahl al-Kitāb tidak semuanya sama, tapi pada satu sisi dia secara tegas mengeneralisasi makna Ahl al-Kitāb. Menurut al-Sa'di, di antara Ahl al-Kitäb dapat ditemukan orang yang taat, patuh, dan senantiasa berbuat kebaikan. Di samping itu, sebagian mereka boleh jadi merupakan ancaman bagi umat Islam. Ancaman yang dimaksud adalah dalam konteks hubungan perekonomian (mu'ämalah) bukan dalam konteks keagamaan. Pandangan ini didasarkan pada sebuah ayat yang menyebutkan peristiwa diamanahkannya harta dan emas kepada sekelompok Ahl al-Kitāb. Sebagian mereka berlaku amanah, tapi sebagiannya pula tidak menggembalikan harta yang dititipkan padanya. ${ }^{61}$

Selain perilaku positif dalam konteks mu'āmalah keseharian, Ahl alKitāb dapat pula dibedakan berdasarkan perilaku peribadatan yang mereka amalkan. Al-Sa'di menyebutkan bahwa di antara Ahl al-Kitāb terdapat diantara mereka yang berjalan lurus mengikuti ajaran Allah dan patuh melaksanakan perintah-Nya. Pada malam hari, mereka beribadah melaksanakan shalat dan membaca kitab secara khushū'. Penafsirannya terhadap QS. Ali 'Imrān [3]: 114

${ }^{61}$ Nāṣir al-Sa‘di, Taysīr al-Karìm al-Raḥmān, 134-135. 
"yu'minūna bi-Allāh wa al-yawm al-akhïr" menjelaskan bahwa disebutkannya keimanan Ahl al-Kitäb hanya kepada Allah dan hari akhir, bukan berarti Ahl alKitāb diperbolehkan untuk tidak beriman dengan ke-Nabi-an Muhammad. Apabila seorang hamba percaya dengan Allah dan hari akhir, maka secara otomatis ia akan terdorong untuk beriman dengan Nabi Muhammad saw. ${ }^{62}$

Golongan Ahl al-Kitāb dapat pula dibagi kepada kelompok yang fasiq dan beriman kepada Allah. Maksud QS. Ali 'Imrān [3]: 114 “yu'minūna biAllāh wa al-yawm al-akhïr," menurut al-Sa'di adalah $A$ hl al-Kitāb yang hidup pada masa sebelum diutusnya Nabi Muhammad saw. Tapi, setelah kedatangan Nabi Muhammad saw dengan membawa syari'at baru, maka diktum tersebut tentunya tidak dapat diberlakukan lagi. Kehadiran Muhammad secara otomatis telah menganulir ketentuan tersebut. Agama yang datang setelah diutusnya Nabi Muhammad saw tidak akan diterima. ${ }^{63}$ Term ummah qa'imah sekiranya dapat mewakili sifat $A h l$ al-Kitäb. Penggunaan kata ini sebagai bentuk pernyataan bahwa di antara $A h l$ al-Kitāb terdapat orang yang berjalan lurus di jalan Allah. Mereka itu adalah orang yang menunaikan shalat, bersujud, dan membaca ayat Allah swt. Perbuatan tersebut menyerupai amal ibadah yang dilakukan oleh umat Islam (Muslim) pada malam hari. ${ }^{64}$

Pandangan di atas juga diperkuat oleh penelitian yang dilakukan oleh Jarot Wahyudi. Ia menyebutkan bahwa penafsiran yang dilakukan oleh para mufasir terhadap QS Ali 'Imrān [3]: 113-115 menunjukkan bahwa Ahl al-Kitāb tidak seluruhnya sama. Sebagian Ahl al-Kitāb terdapat sekelompok orang yang baik dan mengutamakan kebajikan, tapi adapula di antara mereka yang berbuat keji dan berperilaku jahat. Penafsiran ini didasarkan atas penelitiannya kepada sejumlah penafsiran para mufasir seperti Ṭabari, al-Ṭūsi, Zamakhshari, 'Abduh dan Riḍā, Ṭabātabā'ì dan Muhammad Arkoun. ${ }^{65}$

Di samping itu, al-Sa'di juga menamai Ahl al-Kitāb sebagai Ahl al-'Ilmî. Ini disebabkan kepercayaan mereka kepada Allah dan ke-Nabi-an Muhammad yang dapat mengantarkannya takut pada Allah swt. Setiap individu yang takut dan tunduk atas segala yang diperintahkan dapat disebut sebagai orang yang

${ }^{62}$ Nāṣir al-Sa‘di, Taysìir al-Karīm al-Rahmmān, 143-144.

${ }^{63}$ Nāṣir al-Sa'đi, Taysīr al-Karìm al-Raḥmān, 143-144.

${ }^{64}$ Dalam ayat ini tidak dijelaskan bahwa $A h l$ al-Kitāb adalah mareka yang hidup sebelum diutusnya Nabi Muhammad saw. Tapi, patut diduga bahwa berdasarkan penafsiran al-Sa'di dalam ayat sebelumnya, Ahl al-Kitāb yang melakukan perbuatan baik dan akan mendapat balasan berupa pahala di akhirat adalah sebelum diutusnya Nabi Muhammad saw. Nāṣir al-Sa'di, Taysīr al-Karīm al-Raḥmān, 143-144.

${ }^{65}$ Jarot Wahyudi, "Exegetical Analysis of the Ahl al-Kitäb Verses of the Qur'an”, Islamic Studies 37: 4 (1998): 425-442. 
berilmu. Penamaan ini didasarkan pada sebuah nash yang berbunyi "Sesungguhnya orang yang takut dengan Allah pada hari kiamat adalah para ulama (yang berilmu)". Berdasarkan argumen tersebut, maka Ahl al-Kitāb bisa disebut pula sebagai $A h l$ al-'IImī karena ketakutan mereka kepada Allah swt. ${ }^{66}$ Apabila dicermati penafsiran para mufasir baik klasik maupun kontemporer, mereka menyepakati bahwa tidak semua Ahl al-Kitāb berperilaku sama. Di antara mereka terdapat kelompok yang ingkar, menukar, dan mengubah ayat Allah. Tapi, sebagian mereka merupakan umat yang saleh, dan rajin beribadah.

Disamping sikap positif di atas, al-Sa'di menyebutkan bahwa dalam alQur'ān terdapat sejumlah sikap negatif $A$ hl al-Kitāb. Dalam QS al-Baqarah [2]: 105, Allah menjanjikan kepada $A h l$ al-Kitāb (dikhususkan pada Yahudi) azab yang pedih. Janji tersebut disebabkan kaum Ahl al-Kitāb (Yahudi) memusuhi umat Islam. Mereka tidak menghendaki diturunkan sedikit maupun banyak kebaikan pada orang Mukmin, yang disebabkan oleh kebencian dan kemarahan mereka. ${ }^{67}$ Dalam QS al- Baqarah [2]: 109 disebutkan bahwa adanya usaha $A h l$ al-Kitāb untuk memperdaya kaum Muslimin agar kembali ingkar pada Allah. ${ }^{68}$ Apabila mereka tetap berlaku ingkar terhadap ketetapan Allah setelah datang bukti yang nyata, maka Allah akan menempatkannya dalam neraka jahannam. ${ }^{69}$

Berdasarkan penjelasan di atas, penafsiran term al-Yahüd dan alNașāāa (Ahl al-Kitāb) dalam QS al-Baqarah [2]: 120 dan QS al-Mā'idah [5]: 51 tidak dapat digeneralisir karena mereka tidaklah sama seluruhnya. Perilaku non-Muslim kepada umat Islam sangatlah beragam di antaranya terdapat orang yang taat beribadah, amanah, dan terpercaya. Tetapi, di antara Ahl alKitāb terdapat pula orang yang ingkar, tidak amanah serta berbuat keji tarhadap umat Islam. Perbedaan ini semestinya diikuti oleh pemahaman yang proporsional dalam menafsirkan term al-yahūd dan al-nașāāa (Ahl al-Kitāb) dalam al-Qur'ān. Penafsiran yang tidak proporsional dan cenderung mengeneralisir makna akan berdampak pada pengabaian maksud dan tujuan alQur'ān itu sendiri. Dengan demikian, pembacaan teks al-Qur'ān juga meniscayakan adanya pembacaan konteks teks itu sendiri. Tanpa analisis konteks, maka akan sangat beresiko timbulnya produk tafsir yang eksklusif, intoleran dan jauh dari maksud dan tujuan al-Qur'ān. ${ }^{70}$

${ }^{66}$ Nāṣir al-Sa‘di, Taysìir al-Karìm al-Raḥmān, 162.

${ }^{67}$ Nāșir al-Sa‘di, Taysìr al-Karìm al-Raḥmān, 61.

${ }^{68} \mathrm{Nāṣir} \mathrm{al-Sa} \mathrm{di}$, Taysìr al-Karìm al-Raḥmān, 62.

${ }^{69}$ Nāsirir al-Sa'di, Taysìr al-Karìm al-Rahmān, 931.

${ }^{70}$ Lihat Md. Yousuf Ali, "A Contextual Approach to the Views of Muslim Feminist Interpretation of the Qur'an Regarding Women and Their Rights," 314. Lihat 
Selain analisis inter-teks perlu juga dihadirkan tinjauan sejarah terkait interaksi antara umat Islam dan non-Muslim. Perlakuan Nabi Muhammad saw terhadap komunitas Yahudi dan Nasrani di Mekah dan Madinah agaknya dapat dijadikan patokan tentang bagaimana seharusnya memperlakukan non-Muslim. Demikian pula, perlakuan sahabat Nabi ataupun para Khulafă' al-Rāshidin kepada umat agama lainnya. Sejumlah ayat al-Qur'ān juga menegaskan bahwa tidak ada paksaan dalam beragama, dan dialog (co-existence) adalah ajaran fundamental dalam agama Islam. Karena itu, kajian konseptual mengenai relasi Muslim dan non-Muslim menjadi suatu hal yang amat penting untuk dikemukakan.

\section{Muslim dan non-Muslim dalam Tinjauan Sejarah}

Pada masa hidupnya Nabi Muhammad saw, saat kaum Muslim hijrah dari Mekah ke Madinah, Islam tidak disebarkan dengan kekerasan. Ketika umat Islam menjadi agama minoritas di Mekkah, Nabi Muhammad saw melakukan dialog secara berangsur-angsur dan bukan dengan paksaan. Penelitian yang dilakukan oleh Amir Hussain membuktikan bahwa Nabi Muhammad saw dari awal penerimaan wahyu hingga akhir hidupnya secara aktif telah melakukan dialog agama (interfaith dialogue). Ini menunjukkan bahwa penyebaran Islam tidak dilakukan dengan tindak kekerasan. Islam sehendaknya disebarkan dengan mengutamakan dialog. Apalagi, Islam hingga saat ini masih menjadi agama minoritas di Eropa. Pandangan keagamaan yang eksklusif di mana non-Muslim diangap sebagai ancaman, hendaknya dirubah menjadi pemahaman yang lebih toleran. Apabila doktrin ini terus-menerus dipertahankan, maka akan berakibat pada citra Islam yang intoleran dan tidak mengahargai perbedaan. ${ }^{71}$

Nurcholish Madjid, mengutip pendapat ahli sejarah ternama Dimont, menyatakan bahwa non-Muslim (Yahudi dan Nasrani) pernah merasakan indahnya toleransi beragama yang diterapkan pemerintahan Islam di Spanyol. Di mana umat Muhammad, Yahudi, dan Kristen hidup berdampingan untuk mencapai peradaban yang gemilang. Bernard Lewis juga menjelaskan bahwa kawasan Arab yang dekat dengan pusat peradaban Islam adalah sangat toleran terhadap komunitas agama lainnya (non-Muslim). ${ }^{72}$

juga Ingrid Mattson, The Story of the Qur'an: Its History and Place in Muslim Life (Oxford: Blackwell Publishing, 2008), 1-3.

71 Amir Hussain, "Muslims, Pluralism, and Interfaith Dialogue" dalam Progressive Muslims, (ed) Omid Safi (Oxford: One World Publication, 2008), 252-253.

72 Sejarawan ternama, Bernard Lewis menyebutkan bahwa semakin dekat masyarakat Islam ke pusat perkembangan Islam di Timur, maka semakin toleran pula 
Kecurigaan terhadap non-Muslim (Yahudi dan Nasrani) sehendaknya juga tidak disikapi secara berlebihan. Pada masa awal ke-Islam-an, masyarakat Arab yang masuk Islam mendapat pertentangan dari kelompok kafir yang ada di Mekah. Nabi Muhammad saw kemudian menginstruksikan kepada mereka untuk menyebrangi Laut Merah (the Red Sea) untuk sampai ke Abyssinia. Daerah ini adalah wilayah pemerintahan Kristen yang dipimpin oleh seorang Raja Nasrani. Di sini pula para imigran (umat Islam yang hijrah) diterima secara baik. Raja Kristen menjaga umat Islam dari kekejaman kaum kafir yang ada di Mekah. Kaum Muslim-pun tinggal di Abyssinia hingga mereka bergabung lagi dengan komunitas Muslim yang ada di Madinah. ${ }^{73}$ Peristiwa hijrahnya Nabi Muhammad saw beserta para pengikutnya (yang menjadi korban kekejaman kafir Mekah) ke Abyssnia menunjukkan bahwa non-Muslim (khususnya Kristen) mempunyai sikap yang bersahabat dengan umat Islam.

Pada masa hidupnya Nabi Muhammad saw dan Khulafás Rāshidīn, umat Islam memperlakukan non-Muslim secara toleran dan adil. Ini dapat dibuktikan dengan diadakannya sejumlah perjanjian damai. Ketika Nabi Muhammad saw datang ke Yathrib (Madinah sebelum Islam), ia menggagas terwujudnya "Piagam Madinah" yang kemudian menjadi landasan konstitutional negara Islam yang ia dirikan. Pada awalnya, "Piagam Madinah" ini merupakan diktum perjanjian dengan kaum Yahudi saja, tapi setelah meluasnya daerah penyebaran Islam, perlindungan juga diberikan kepada Kristen Arab dari Najran. Pada tahun berikutnya, pemeluk agama Majusi (di wilayah timur semananjung Arabia seperti Bahrain dan penduduk Hajr) juga diberikan hak perlindungan. ${ }^{74}$

umat Islam kepada pengikut agama lainnya, kecuali terhadap Muslim di Spanyol yang sangat toleran dan komunitas Muslim di Hijaz, yang tidak diperbolehkan adanya agama selain Islam. Nurcholish Madjid, "Interpretating the Quranic Principle of Religious Pluralism", dalam Approaches to the Qur'an in Contemporary Indonesia (ed), Abdullah Saeed (New York: Oxford University Press, 2005), 215.

73 Amir Hussain, "Muslims, Pluralism, and Interfaith Dialogue" dalam Progressive Muslims, (ed) Omid Safi (Oxford: One World Publication, 2008), 253.

${ }^{74}$ Anis Malik Thoha, Tren Pluralisme Agama: Tinjauan Kritis (Jakarta: Gema Insani, 2005), 219-223. Al-Shahrastani dalam al-Milal wa an-Nihal membagi kaum Majusi kepada tiga sekte utama, yaitu Kayumartiyah, Zarwaniyah, dan Zaradushttiyah. Zaradushttiyah adalah pengikut Zoroaster. Menurutnya, al-Majusisi bukanlah Ahl alKitāb, tapi mereka hanya memiliki kitab inspirasi (Shubhat Kitäb). Dalam Islam, kaum Majusi diperlakukan sebagai $A h l$ al-Kitāb. Ini disebabkan sebelum munculnya Majüsiyyah, bangsa Persia mengakui agama Nabi Ibrahim AS, yaitu monotheisme (alhanafiyyah). M.A. Muhibbu-Din, "Ahl al-Kitāb and Religious Minorities in the Islamic State: Historical Context and Contemporary Challenges", Journal of Muslim Minority Affairs, 20: 1 (2000): 111-127: 111-112. 
Pada masa Khulafá', al-Rāshidìn, kelompok masyarakat telah terdiri dari berbagai agama, suku, mazhab, dan tradisi. Sebagai respons perkembangan tersebut, para Khulafá' al-Rāshidin meneladani perilaku yang dilakukan Nabi Muhammad saw semasa hidupnya. Pada masa berikutnya ditemui pula umat Sabean, Hindu, dan Budha karena Islam telah tersebar ke wilayah anak benua India di bawah komando Muḥammad ibn al-Qāsim. Khalifah 'Umawiyyah kemudian menetapkan bahwa para pemeluk Hindu dan Budha diperlakukan sama dengan umat Yahudi dan Nasrani. Mereka akan mendapatkan perlindungan dari pemerintahan Islam, selama ia mengikuti peraturan dan membayar jizyah. Perjanjian di atas menunjukkan bahwa Islam sangat berkomitmen untuk membangun tatanan masyarakat yang berlandaskan pada toleransi dan keadilan. ${ }^{75}$

Meski demikian, konsep Islam tentang “jihàd” acapkali dijadikan alasan untuk menjustifikasi bahwa Islam adalah agama yang intoleran dan penuh dengan kekerasan. Klaim tersebut agaknya perlu dikritisi baik secara konseptual dan historis ke-Islam-an. Secara konseptual, ayat al-Qur'ān jelas menegaskan bahwa tidak ada paksaan dalam beragama QS [2]: 256, [10]: 99, dan [18]: 29. Analisis historis dapat pula dijadikan argumen yang kuat bagaimana Islam mempraktekkan ajaran tersebut. Penyebaran Islam di Balkan, Semananjung Iberian, dan Asia Selatan membuktikan bahwa Islam bukanlah agama yang disebarkan dengan pedang. Meskipun, daerah tersebut diperintah oleh umat Islam, tapi penyebaran Islam di wilayah tersebut butuh waktu hingga 500 tahun. Islam juga tidak memiliki doktrin perang suci (the holy war), melainkan Nabi Muhammad saw sendiri menyatakan bahwa perang terbesar itu adalah melawan hawa nafsu. Sementara itu, beliau baru saja terlibat perang fisik yang amat dahsyat di perang Badar. ${ }^{76}$

Bernard Lewis menyatakan bahwa dibandingkan perlakuan yang diberikan oleh pemerintah non-Muslim (Yahudi dan Nasrani), maka pemerintahan Islam adalah lebih toleran kepada pemeluk non-Muslim. Bernard Lewis mengungkapkan sejarah panjang interaksi Muslim dan non-Muslim. Tak dapat dipungkiri bahwa selain terdapat sikap toleran terhadap non-Muslim, juga terjadi peristiwa-peristiwa intoleransi terhadap komunitas agama lainnya. Sikap tersebut masih terbilang wajar apabila dibandingkan dengan sikap pemerintah non-Muslim terhadap komunitas Muslim. Ia menduga bahwa terjadinya

${ }^{75}$ Anis Malik Thoha, Tren Pluralisme Agama: Tinjauan Kritis, 223-231.

${ }^{76}$ Farhan Mujahid Chak, "La Convicencia: The Spirit of Co-Existence in Islam”, Islamic Studies 48: 4 (2009): 567-590: 586-585. . 
tindakan intoleransi disebabkan oleh kekuatan pemerintahan Islam pada masa itu yang masih lemah. Dengan demikian, teori yang dibangunnya adalah semakin kuat sebuah pemerintahan maka peluang untuk bertoleransi lebih besar dibandingkan pemerintahan yang masih lemah. Ini dilakukan untuk menjaga dominasinya terhadap komunitas lainnya. ${ }^{77}$

Bernard Lewis menyebutkan hubungan antara Muslim dan non-Muslim dalam sejarah peradaban dunia, sebagai berikut:

\begin{abstract}
"Christendom and Islam are in many ways sister civilizations, both drawing on the shared heritage of Jewish revelation and prophecy and Greek philosophy and science, and both nourished by the immemorial traditions of Middle Eastern antiquity. For most their joint history, they have been locked in combat, in an endless series of attacks and counter attacks, jihads and crusades, conquest and reconquest. But even in struggle and polemic they reveal their essential kindship and the common features which link them to each other and set them apart from the remoter civilizations of Asia."78
\end{abstract}

Islam memberikan kebebasan bagi minoritas agama untuk menjalankan kepercayaannya. Islam berupaya mentolerir perbedaan yang terjadi antara mayoritas Muslim dan minoritas non-Muslim. Itulah sebabnya, Islam tidak memisahkan agama dan negara (secular state) sebagaimana yang dilakukan oleh Barat. Islam memberikan ruang seutuhnya bagi masing-masing pemeluknya untuk menjalankan ajaran agama sesuai dengan keyakinan yang dianutnya. ${ }^{79}$ Praktek ajaran Islam dalam hal beragama juga telah dicontohkan oleh Nabi Muhammad saw ketika beliau memimpin tiga komunitas agama besar, Islam, Nasrani, dan Yahudi di Madinah. Sejarah menunjukkan bahwa Nabi sama sekali tidak pernah mengekang hak dan memaksa non-Muslim agar menganut agama Islam. Bahkan, ketika terjadi pembebasan Mekah (fath al-Makkah), Nabi Muhammad saw tetap menghormati "tuhan" agama Yahudi dan Nasrani. ${ }^{80}$

${ }^{77}$ Bernard Lewis, The Jews of Islam, 10-60.

${ }^{78}$ Bernard Lewis, Islam in Hostory: Ideas, People, and Events in the Middle East (Chicago: Open Court Publishing, 2001), 261.

79 Ahmad Yousif, "Islam, Minorities and Religious Freedom: A challenge to Modern Theory of Pluralism," Journal of Muslim Minority Affairs, 20:1 (2000): 29-41.

${ }^{80}$ Obaidullah Fahad, "Tracing Pluralistic trends in Sirah literature: A Study of Some Contemporary Scholars," Islamic Studies, 50:2 (2011): 217-243. 
Ketika Nabi Muhammad saw berada di Mekah, umat Islam disiksa dan diperlakukan secara keji. Perlakuan ini menyebabkan Nabi beserta pengikutnya hijrah ke Madinah. Setelah berada di Madinah, umat Islam di bawah kepemimpinan Muhammad sukses melakukan konsolidasi. Nabi Muhammad saw telah mempunyai kekuatan yang amat besar. Umat Islam bertambah secara signifikan. Ketika Nabi Muhammad saw kembali ke Mekah, dengan kekuatan militer yang besar pada tahun $622 \mathrm{H}$, ia bisa saja menaklukkan Mekah dan memerangi orang yang dahulu membunuh, dan menyiksa ia dan pengikutnya. Akan tetapi setelah membebaskan Mekah (fath al-Makkah), ia memaafkan umat Kristen dan Yahudi. Ini menunjukkan bahwa spirit dasar keislaman adalah sprit toleransi dan cinta damai, bukan spirit peperangan dan kekerasan. Ajaran seperti inilah yang juga diikuti oleh pemimpin dan khalifah berikutnya, seperti 'Umar bin Khaṭab dan khalifah Harūn al-Rashìd. ${ }^{81}$

Pengakuan terhadap agama lain yang dirumuskan dalam konsep $A h l$ alKitāb merupakan gagasan yang sangat luar biasa dalam sejarah agama-agama. ${ }^{82}$ Mun'im A Sirry menyebutkan bahwa konsep Ahl al-Kitāb ini bertujuan untuk memajukan budaya dan peradaban Islam dengan cara membuka peluang munculnya kosmopolitanisme dan tata masyarakat yang terbuka dan toleran. ${ }^{83}$ Bernard Lewis dalam bukunya the Jews of Islam menceritakan bahwa sejarah menunjukkan telah terjadi kerjasama budaya yang intens antara Muslim dan non-Muslim (Kristen dan Yahudi). Kerjasama budaya ini dibuktikan dengan banyak cara. Misalnya, ditemukannya kamus biografi para dokter yang terkenal. Dari sumber-sumber ini kita mendapatkan gambaran yang jelas tentang adanya usaha bersama. Di rumah-rumah sakit dan tempat praktek pribadi, para dokter dari tiga agama itu bekerjasama sebagai rekan atau asisten, saling membaca buku mereka dan saling menerima yang lain sebagai murid. Tidak ada yang menyerupai semacam pemisahan yang biasa didapati di dunia Kristen Barat pada masa itu atau di dunia Islam pada masa kemudian. ${ }^{84}$

Informasi di atas memperlihatkan bahwa Islam memiliki konsep yang terbuka dan toleran terhadap keyakinan kelompok agama lainnya. Fakta sejarah membuktikan bahwa hubungan Muslim dan non-Muslim tidak selalu diwarnai oleh tindak kekerasan yang dapat memicu terjadinya pertumpahan darah. Dua

81 Amir Hussain, "Muslims, Pluralism, and Interfaith Dialogue" dalam Progressive Muslims, (ed) Omid Safi (Oxford: One World Publication, 2008), 251-269.

${ }^{82}$ Cyril Glasse, "Ahl al-Kitāb," dalam The Concise Encyclopaedia of Islam (London: Stacey International, 1989), 27-28.

${ }^{83}$ Nurcholish Madjid, Fiqih Lintas Agama, 42-43.

${ }^{84}$ Bernard Lewis, The Jews of Islam, 16-17. 
kelompok ini juga pernah merasakan hidup secara berdampingan yang didasarkan pada prinsip toleransi. Bahkan, Raja Kristen-pun semasa hidup Nabi Muhammad saw pernah melindungi umat Islam dari kejaran kaum Kafir. Dengan demikian, generalisasi makna $A h l$ al-Kitāb yang disebutkan dalam alQur'ān adalah penafsiran yang tidak tepat. Anggapan bahwa semua Ahl alKitāb adalah musuh (berniat buruk terhadap umat Islam) tentunya penafsiran yang tidak memperhatikan sejarah dan cenderung parsial. Karena itu, penyebutan kata $A$ hl al-Kitāb dalam al-Qur'ān hendaknya tidak dipahami secara tekstual dengan menyamakan seluruh Ahl al-Kitāb.

Terkait fakta di atas, perbedaan sikap Ahl al-Kitāb terhadap umat Islam amat menentukan sikap yang mesti diambil oleh umat Islam itu sendiri. Dalam proses debat (jadāl) misalnya, apabila $A h l$ al-Kitāb berperilaku baik dan tidak menyerang umat Islam, maka seorang Muslim hendaknya berdebat pula secara baik dan santun. Tapi, apabila mereka berlaku ingkar, keji, dan hendak menyerang umat Islam, maka sebaiknya hindarilah perdebatan dengan golongan Ahl al-Kitäb. Ini dikarenakan debat yang hendak dilakukan tidak akan mendatangkan manfaat. Bahkan, dapat saja menimbulkan mafsadāt. Penjelasan ini menunjukkan bahwa tidak semua $A h l$ al-Kitāb dapat diperlakukan sama dan bisa digeneralisir seluruhnya. ${ }^{85}$ Karena itu, sejumlah ayat al-Qur'ān yang menyebutkan term $A h l$ al-Kitāb dengan konotasi negatif hendaknya ditafsirkan dengan memperhatikan konteks penyebutan kata tersebut. Dengan cara ini, maka maksud dan tujuan ayat al-Qur'ān dapat dipahami secara benar. ${ }^{86}$

\section{Kesimpulan}

Penelitian ini menyimpulkan bahwa penafsiran yang hanya berorientasi pada teks dan mengabaikan analisis konteks (saat teks diwahyukan dan hendak ditafsirkan) akan mengakibatkan produk tafsir yang cenderung eksklusif. Penafsiran model ini tentunya tidak akan dapat menunjang terwujudnya dialog antar umat beragama. Non-Muslim sudah terlanjur dipandang sebagai "musuh" yang akan senantiasa berniat buruk terhadap umat Islam. Hal ini dibuktikan dengan penafsiran al-Sa'di terhadap QS al-Baqarah [2]: 120 dan QS al-Mā'idah [5]: 51. Ayat pertama menjadi dasar justifikasi bahwa non-Muslim khususnya Yahudi dan Nasrani tidak akan rela terhadap umat Islam dan akan senantiasa

${ }^{85}$ Nāsir al-Sa‘di, Taysìr al-Karìm al-Rahmān, 632.

86 Baca Md. Yousuf Ali, "A Contextual Approach to the Views of Muslim Feminist Interpretation of the Qur'an Regarding Women and Their Rights", International Journal of Art and Sciences 3, 13 (2010): 316. 
proaktif mengajak umat Islam supaya mengikuti agama mereka. Adapun QS alMā'idah [5]: 51 merupakan argumen supaya non-Muslim tidak diangkat menjadi awliyāa ataupun pemimpin bagi umat Islam. Ini disebabkan mereka akan membawa umat Islam pada keburukan dan kekafiran. Penafsiran model ini tent unya tidak akan dapat menunjang terwujudnya dialog antar umat beragama yang merupakan tujuan dasar ajaran Islam itu sendiri. Dengan demikian, seorang penafsir hendaknya tidak saja melakukan analisis tekstual ayat alQur'ān tapi juga menganalisis konteks teks itu sendiri. Konteks tersebut hendaknya dilakukan dengan membaca ayat al-Qur'ān secara komprehensif sehingga diperoleh maksud dan tujuan al-Qur'ān yang sebenarnya. Selain itu, sikap dan perlakuan Rasul dan para Sahabat terhadap non-Muslim harusnya dijadikan patokan dalam berinteraksi antara umat Islam dan non-Muslim.

\section{Daftar Pustaka}

Abū Zayd, Nașr Hāmid Abū. Mafhūm al-Nașs: Dirāsa fí 'Ulūm al-Qur'ān. Beirut: al-Markaz al-Thaqāfū al-'Arabī, 1990.

Amal, Taufik Adnan dan Syamsul Rizal Pangabean. "A Contextual Approach to the Qur'an." Dalam Approaches to the Qur'an in Contemporary Indonesia (ed) Abdullah Saeed. Oxford: Oxford University Press, 2005.

Bennett, Clinton, Interpreting the Qur'an: A Guide for the Uninitiated. London: Continuum, 2010.

Campanini, Massimo. The Qur'an: Modern Muslim Interpretations, terj. Caroline Higgitt. London dan New York: Routledge, 2011.

Duderija, Adis. "Construction of the Religious Self and the other: The Progressive Muslims' Manhaj" Studies in Contemporary Islam 10, 1-2 (2008).

------. "The Interpretational Implications of Progressive Muslims' Qur' an and Sunna Manhaj in Relation to their Formulation of a Normative Muslima Construct." Islam and Christian-Muslim Relations 19,4 (2008): 411-429.

------. "Islamic Groups and their World-views and Identities: Neo-Traditional Salafis and Progressive Muslims," Arab Law Quarterly 21 (2007): 339360

-----. 'Neo-Traditional Salafi Qur'an-Sunna Hermeneutics and Its Interpretational Implications,” Religion Compass 5, 7 (2011). 
------. "Progressive Muslims- Defining and Delineating Identifies and Ways of

Being a Muslim," Journal of Muslim Minority Affairs 30, 1 (2010).

Esack, Farid. The Qur'an: A Short Introduction, terj. Norma Arbi'a Juli

Setiawan. Depok: Inisiani Press, 2004.

------. Menghidupkan al-Qur'ān: Dalam Wacana dan Perilaku. Depok: Inisiani Press, 2004.

------. Qur'an, Liberation, and Pluralism: An Islamic Perspective if Interreligious Solidarity against Oppression. Oxford: Oneworld, 1998.

Fahad, Obaidullah. "Tracing Pluralistic trends in Sirah literature: A Study of Some Contemporary Scholars." Islamic Studies, 50:2 (2011): 217-243.

Glasse, Cyril. “Ahl al-Kitāb." Dalam The Concise Encyclopaedia of Islam. London: Stacey International, 1989.

Ibn 'Abbās. Tanwīr al-Miqbās min Tafsìir Ibn 'Abbās. Beirut: Dār al-Fikr, 1995. Ibn Kathïr. Tafsìr al-Qur'ān al-Azịm. Beirut: Dār Kutub al-'Ilmiyyah, 1997.

Lewis, Bernard. Islam in Hostory: Ideas, People, and Events in the Middle East.

Chicago: Open Court Publishing, 2001.

Madjid, Nurcholish. Fiqih Lintas Agama: Membangun Masyarakat InklusifPluralis. Jakarta: Paramadina, 2004.

------. "Interpretating the Quranic Principle of Religious Pluralism", dalam Approaches to the Qur'an in Contemporary Indonesia (ed), Abdullah Saeed. New York: Oxford University Press, 2005.

------. Islam, Doktrin, dan Peradaban: Sebuah Telaah Kritis tentang Masalah

Keimanan, Kemanusiaan, dan Kemodernan. Jakarta: Paramadina, 1992.

Mattson, Ingrid. The Story of the Qur'an: Its History and Place in Muslim Life. Oxford: Blackwell Publishing, 2008.

Muhibbu-Din, M. A. "Ahl al-Kitāb and Religious Minorities in the Islamic

State: Historical Context and Contemporary Challenges." Journal of Muslim Minority Affairs, 20: 1 (2000): 111-127.

al-Qarni, Aid. Tafsir al-Muyassar. Madinah Munawwarah: Mushaf Sharif, 2009. Rahman, Fazlur. Islam. Bandung: Penerbit Pustaka, 2000.

------. Islam and Modernity: Transformation of An Intellectual Tradition.

Chicago dan London: The Universiy of Chicago Press, 1984.

------. Major Themes of the Qur'an. Chicago: Bibliotheca Islamica, 1980.

Rohman, Izza. "Aḍ̂ā' al-Bayān Karya al-Shinqițī sebagai Kitab Tafsìr alQur'ān bi al-Qur'ān," Journal of Qur'an and Hadith Studies 2, 2 (2013).

-----. "Salafi Tafsirs: Textualist dan Authoritarian" Journal of Qur'an and Hadith Studies 1, 2 (2012). 
al-Ṣābūnī, Muhammad 'Ali. Al-Ṭibyān fì 'Ulūm al-Qur'ān. Jakarta: Dār alKutub al-Islamiyyah, 2003.

Sachedina, Abdulazis. "The Qur' an and other Religions", dalam The Cambridge Companion to the Qur'an, (ed). Jane Dammen McAuliffe. New York: Cambridge University Press, 2006.

al-Sa'di, Nāṣir. Taysīr Karīm al-Raḥmān: Fì Tafsìr Kalām al-Mannān. Riyad: Dār al-Salām, 2002.

Saeed, Abdullah. Interpretating the Qur'an: Towards a contemporary approach. London dan New York: Routledge, 2006.

------. Islamic Banking and Interest: a Study of Riba and Its Contemporary Interpretation. Leiden dan New York: E. J. Brill, 1996.

------. Reading the Qur'an in the Twenty-first Century: A Contextualist Approach. London and New York: Routledge, 2014.

-----. The Qur'an: An Introduction. London and New York: Routledge, 2008.

Safi, Omid (ed). Progressive Muslims: on Justice, Gender, and Pluralism. Oxford: Oneworld Publications, 2004.

Saritoprak, Zeki dan Sidney Griffith. "Fethullah Gulen and the 'People of the Book': A Voice from Turkey for Interfaith Dialogue." The Muslim World, 95, 3 (2005): 329-340.

Scott, Rachel M. “A Contextual Aprroach to Women's Rights in the Qur'an: Radings of 4:34," The Muslim World 99, 1 (2009).

al-Wāhidi, Ahmad. Asbāb al-Nuzūl al-Qur'ān. Beirut: Dār al-Kutub al'Ilmiyyah, 1991.

Wahyudi, Jarot, “Ahl al-Kitāb in the Qur'an: An Analysis of Selected classical and Modern Exegesis.” Institute of Islamic Studies, McGill University, Montreal, Canada, 1997.

Yousif, Ahmad. "Islam, Minorities and religious Freedom: A Challenge to Modern Theory of Pluralism." Journal of Muslim Minority Affairs, 20: 1 (2000): 29-41. 